OECD Economics Department Working Papers No. 1101

\author{
Getting Irish Youth \\ on the Job Track
}




\section{Unclassified}

ECO/WKP(2013)93

Organisation de Coopération et de Développement Économiques

Organisation for Economic Co-operation and Development

09-Dec-2013

ECONOMICS DEPARTMENT

English - Or. English

GETTING IRISH YOUTH ON THE JOB TRACK

ECONOMICS DEPARTMENT WORKING PAPERS No. 1101

By Alberto González Pandiella

All Economics Department Working Papers are available through OECD's Internet website at http://www.oecd.org/eco/Workingpapers

JT03350232

Complete document available on OLIS in its original format

This document and any map included herein are without prejudice to the status of or sovereignty over any territory, to the delimitation of international frontiers and boundaries and to the name of any territory, city or area. 


\section{ABSTRACT/RESUMÉ}

\section{Getting Irish youth on the job track}

Irish youth was hit hard by the crisis. Many young workers have remained unemployed for a long time and, unless it is tackled promptly, this issue will become one of the most enduring legacies of the recession. New labourmarket policy initiatives have been introduced recently, but more will be needed to limit scarring effects and keep youth connected so that they can get back to work as soon as the recovery strengthens. For many young workers learning new skills is the way to get ready. The Irish economy is shifting away from bricks and mortar towards knowledge-based services, and those previously employed in construction-related activities need to acquire the skills and competencies required in these expanding sectors. For those who have already drifted into more marginalised environments, a longer process of rehabilitation will be necessary to escape poverty and social exclusion. This chapter recommends focusing limited fiscal resources on policies empirically-proven to help regain employment; this will require systematic and rigorous evaluation of labour-market programmes and policy decisions to close down ineffective schemes while strengthening successful ones.

This working paper relates to the 2013 Economic Survey of Ireland (www.oecd.org/eco/surveys/ireland)

JEL Classification: J21; J24; J60; J88; I28

Keywords: Ireland, labour market, youth, unemployment, Not in Education, Employment, or Training, labour market programmes, education, vocational educational, apprenticeship, youth entrepreneurship, disadvantaged youth

$* * * * * * * * * * *$

\section{Favoriser l'emploi des jeunes en Irlande}

En Irlande, les jeunes ont été durement touchés par la crise. Le chômage de longue durée frappe un grand nombre d'entre eux : si les autorités ne s'attaquent pas rapidement à ce problème, il pourrait devenir l'une des conséquences les plus durables de la récession. De nouvelles politiques actives du marché du travail ont été lancées récemment mais il faudra faire plus pour limiter les effets stigmatisants du chômage des jeunes et les préparer à reprendre un emploi dès que la reprise sera plus solide. Pour se préparer, la solution pour de nombreux jeunes travailleurs consiste à acquérir de nouvelles compétences. L'économie irlandaise se détourne progressivement des secteurs d'activité traditionnels au profit des services fondés sur le savoir : ceux qui travaillaient auparavant dans le secteur de la construction doivent donc désormais acquérir les qualifications requises dans ces secteurs d'activité en expansion. Pour les plus marginalisés, un processus de réadaptation plus long sera nécessaire afin d'échapper à la pauvreté et à l'exclusion sociale. Il est recommandé de cibler les ressources budgétaires limitées sur les politiques les plus efficaces en matière de retour à l'emploi, ce qui passe par une évaluation systématique et rigoureuse des programmes du marché du travail et par des choix stratégiques pour mettre un terme aux programmes inefficaces et redéployer les ressources vers les programmes les plus performants.

Ce Document de travail se rapporte à l'Étude économique de l'OCDE de l'Irlande, 2013 (www.oecd.org/eco/etudes/irlande)

Classification JEL : J21; J24 ; J60 ; J88 ; I28

Mots-clés : Irlande, marché du travail, jeunes, chômage, non pas dans l'éducation, l'emploi ou la formation, les programmes du marché du travail, l'éducation, l'éducation professionnelle, apprentissage, l'entreprenariat des jeunes, les jeunes défavorisés acknowledgment of OECD as source and copyright owner is given. All requests for commercial use and translation rights should be submitted to rights@oecd.org 


\section{TABLE OF CONTENTS}

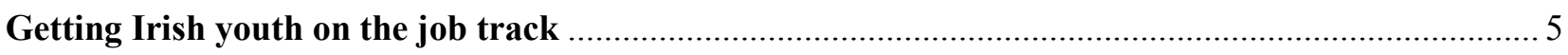

The situation of youth in Ireland's labour market................................................................................ 5

Ensuring active labour market and benefit policies better support young unemployed......................... 17

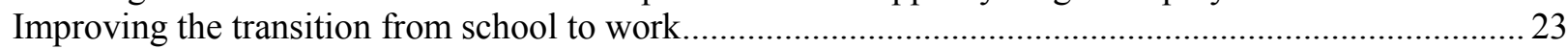

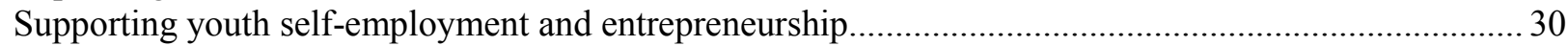

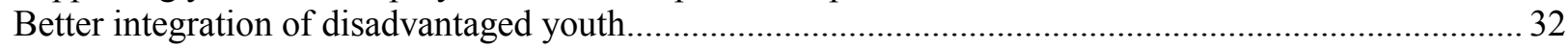

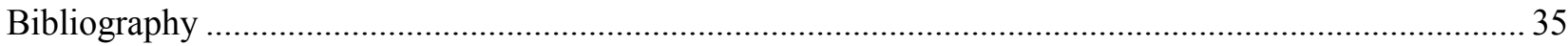

\section{Tables}

1. Trends in Department of Social protection employment support schemes (EUR million).................. 22

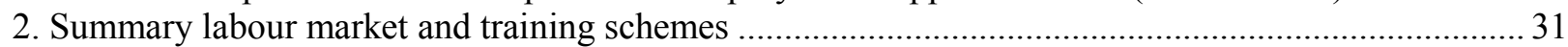

\section{Figures}

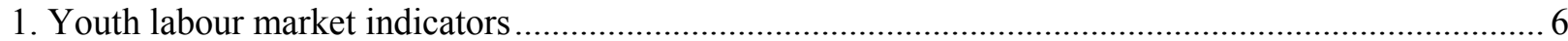

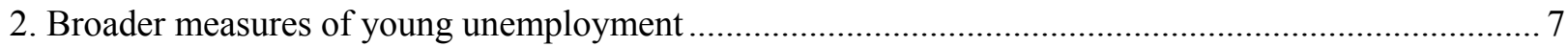

3. Youth employment rates by sex, age and highest level of education attained ..................................... 7

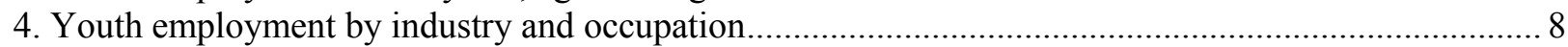

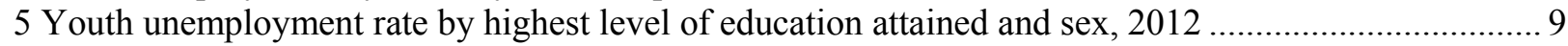

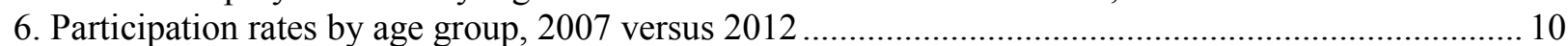

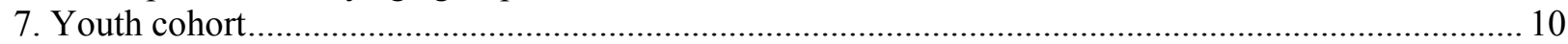

8. Share of long-term unemployment in total youth ${ }^{1}$ unemployment, 2007 versus 2012 ..................... 11

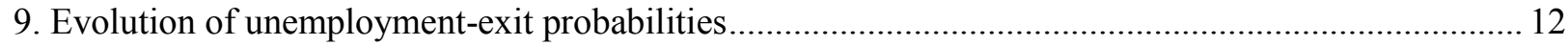

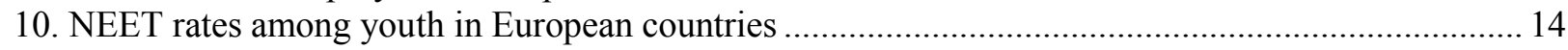

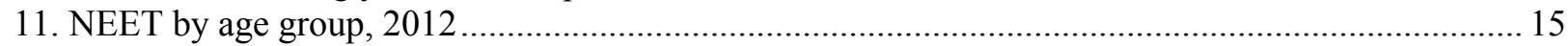

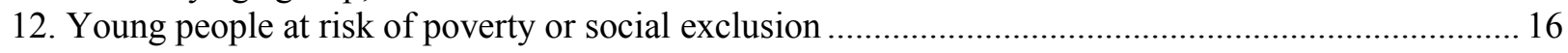

13. Total suicide and intentional self-harm death rates per 100000 for $15-29$ years olds....................... 17

14. Public expenditure on Labour Market Programmes: main categories ............................................. 18

15. Young participants on Labour Market Programmes: main measures ............................................. 19

16. Employment rates of individuals with vocational and general education attainment at ISCED 3-4

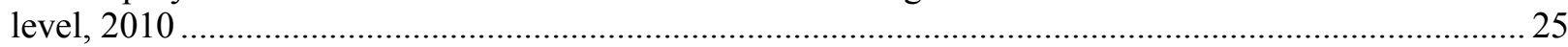

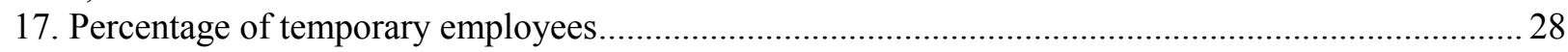

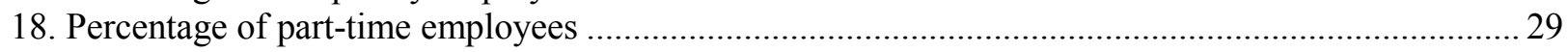

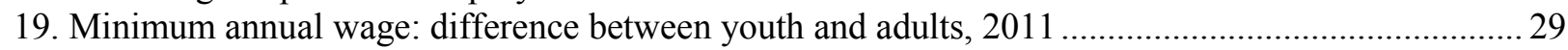

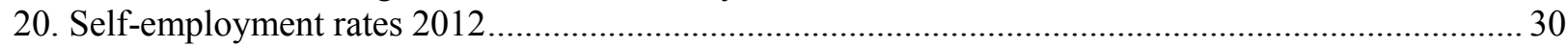

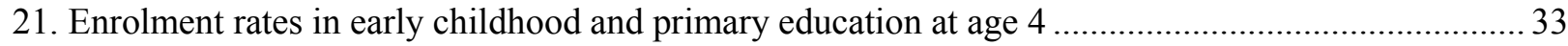

\section{Boxes}

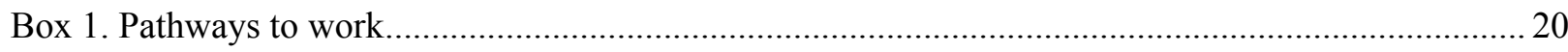

Box 2. SOLAS, the new Further Education and Training Authority ................................................... 24 


\section{ECO/WKP(2013)93}

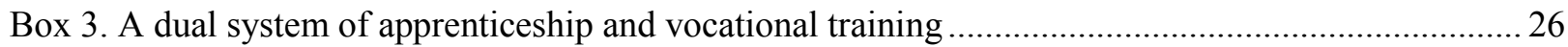

Box 4. Recommendations for getting Irish youth on the job track........................................................ 34

The statistical data for Israel are supplied by and under the responsibility of the relevant Israeli authorities. The use of such data by the OECD is without prejudice to the status of the Golan Heights, East Jerusalem and Israeli settlements in the West Bank under the terms of international law. 
ECO/WKP(2013)93

\title{
GETTING IRISH YOUTH ON THE JOB TRACK
}

\author{
By Alberto González Pandiella ${ }^{1}$
}

The youth unemployment rate has risen sharply since the onset of the crisis and reached an historical high in 2012. Of special concern is that about half of unemployed youth have been out of work for more than a year. Such long-term youth unemployment risks having large and enduring negative implications, as shown by past experience (Martin and Manning, 1999; Bell and Blanchflower, 2011). It is associated with deskilling, permanent scarring effects and a rise of the structural unemployment rate, which would imply that those worst affected would drift into social exclusion and would no longer be able to participate in normal economic activities. Moreover, younger cohorts of workers typically introduce new skills and innovative expertise into the production processes, thus raising the overall productivity level (Lalkemond and Ryckx, 2009; Prskawetz et al., 2006). Maintaining youth excluded from the labour market would, therefore, have seriously damaging repercussions on Ireland's growth potential. It would also have a large cost for the society as it is associated with welfare dependency, risk of poverty and fall into marginalisation and social exclusion. Unless the youth unemployment problem is tackled head-on, these large personal, economic and societal costs risk being among the most enduring and negative legacies of the recession.

This chapter first describes the situation of youth in Ireland's labour market by reviewing recent developments as described by a number of key economic and social indicators. It then discusses the role that labour market policies can play in limiting the negative impact of unemployment and in facilitating the reintegration to work. Afterwards, it examines ways to improve the transition from education to work, and it follows with a review of ways to support youth self-employment and entrepreneurship. Last, the chapter considers how to better integrate youth in more disadvantaged circumstances into the labour market.

\section{The situation of youth in Ireland's labour market}

The youth employment rate in Ireland has fallen sharply since the recession, declining from about $50 \%$ to $30 \%$, which is its historical minimum and well below the OECD average (Figure 1). The unemploymentto-population ratio, calculated by dividing the number of 15-24 year old unemployed people by the total population aged 15-24 years, increased by nearly 7 percentage points after the crisis and currently stands at $12 \%$, well above the OECD average. The unemployment-to-labour supply ratio has also increased sharply, by 20 percentage points to $30 \%$, the highest level recorded since the mid-1980s and significantly higher than the OECD average. The exposure of youth to the risk of unemployment had

1. This paper was originally prepared for the OECD Economic Survey of Ireland published in September 2013 under the authority of the Economic and Development Review Committee. Alberto González Pandiella is Economist in the Economics Department at the OECD. He has greatly benefited from valuable input and comments by Shruti Singh, Andrew Dean, Robert Ford, Patrick Lenain and David Haugh, statistical assistance by Josette Rabesona. The views expressed are those of the author, and not necessarily those of the OECD or its member countries. 
already increased prior to the crisis, as shown by the ratio of youth to adult unemployment but has fallen in recent years. This contrasts with the OECD average, which has remained constant since the 1990s. Broader measures of unemployment, including discouraged workers and involuntary part-time workers, show about half of active young people are under-employed, nearly twice as much as for the total working-age population (Figure 2).

Figure 1. Youth' labour market indicators

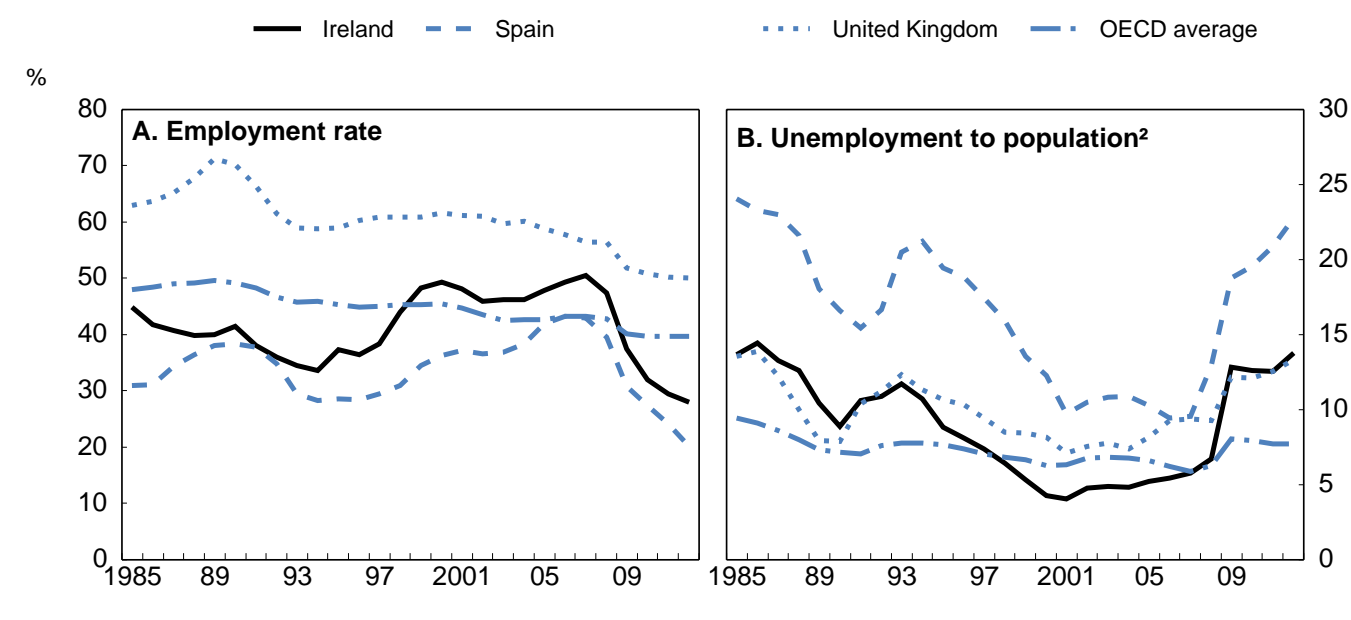

$\%$
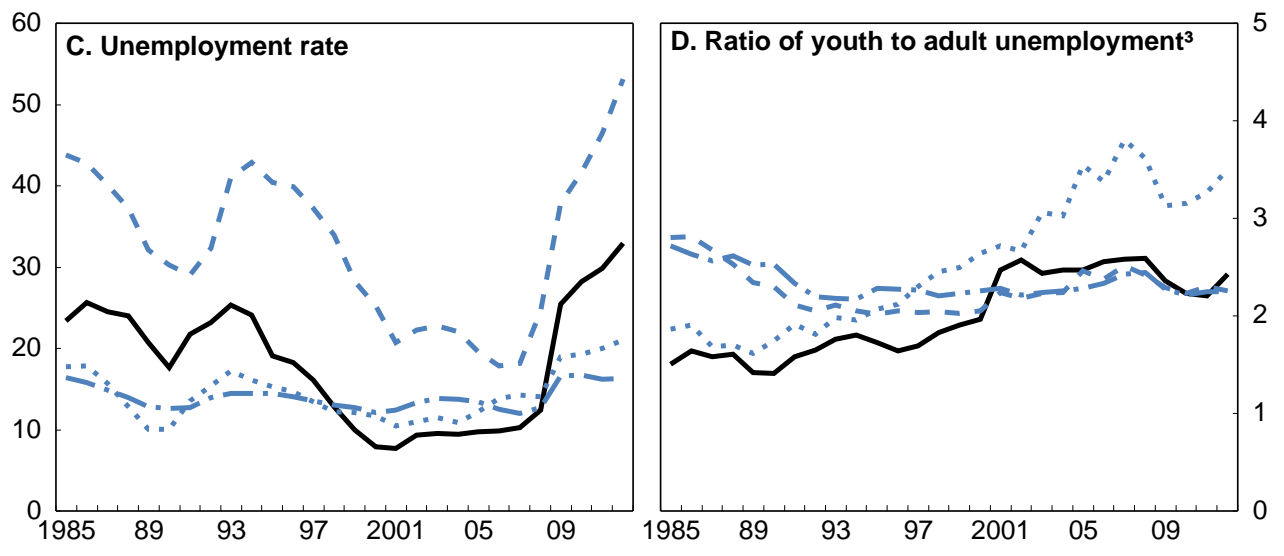

1. Persons aged $15-24$.

2. Unemployed as a percentage of the population in the age group.

3. Unemployment rate of youth (15-24) divided by unemployment rate of adult (25-54).

Source: OECD Labour Force Statistics database. 
Figure 2. Broader measures of young unemployment
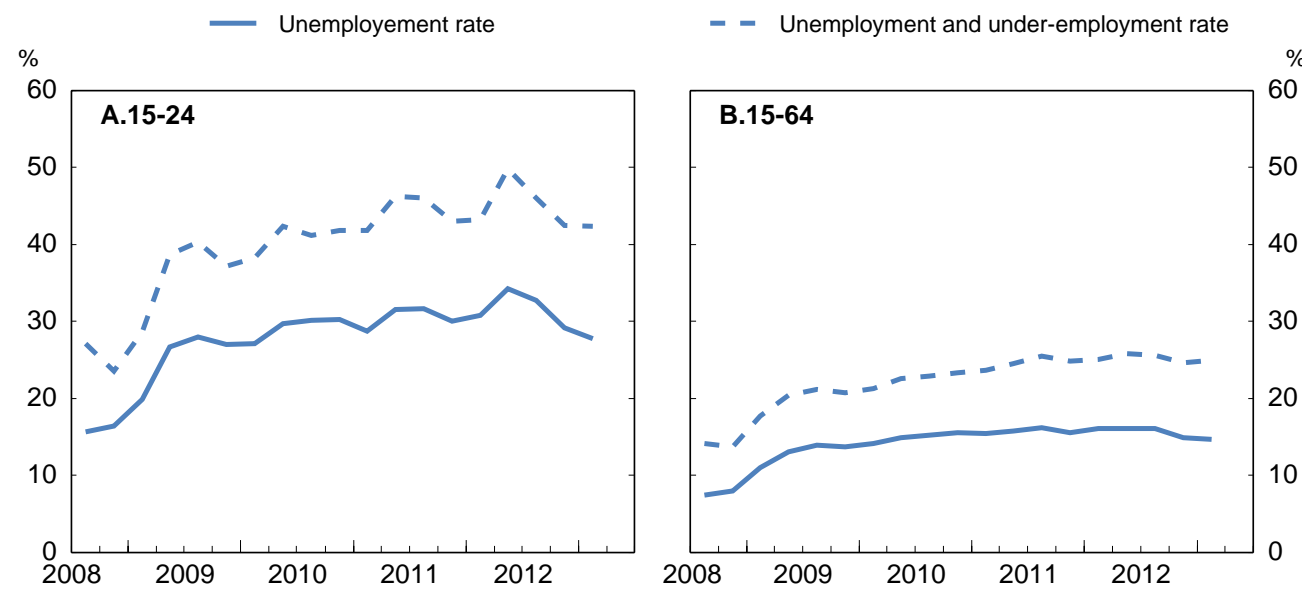

Source: Central Statistics Office.

Young people from all educational backgrounds have been affected (Figure 3), including those with tertiary education. Men with upper secondary education and those with less than secondary education have been greater for women with the same level of education. This reflects the large number of young male workers in construction-related activities during the cyclical upswing.

Figure 3. Youth employment rates by sex, age and highest level of education attained

Difference between 2007 Q4 and 2013 Q1

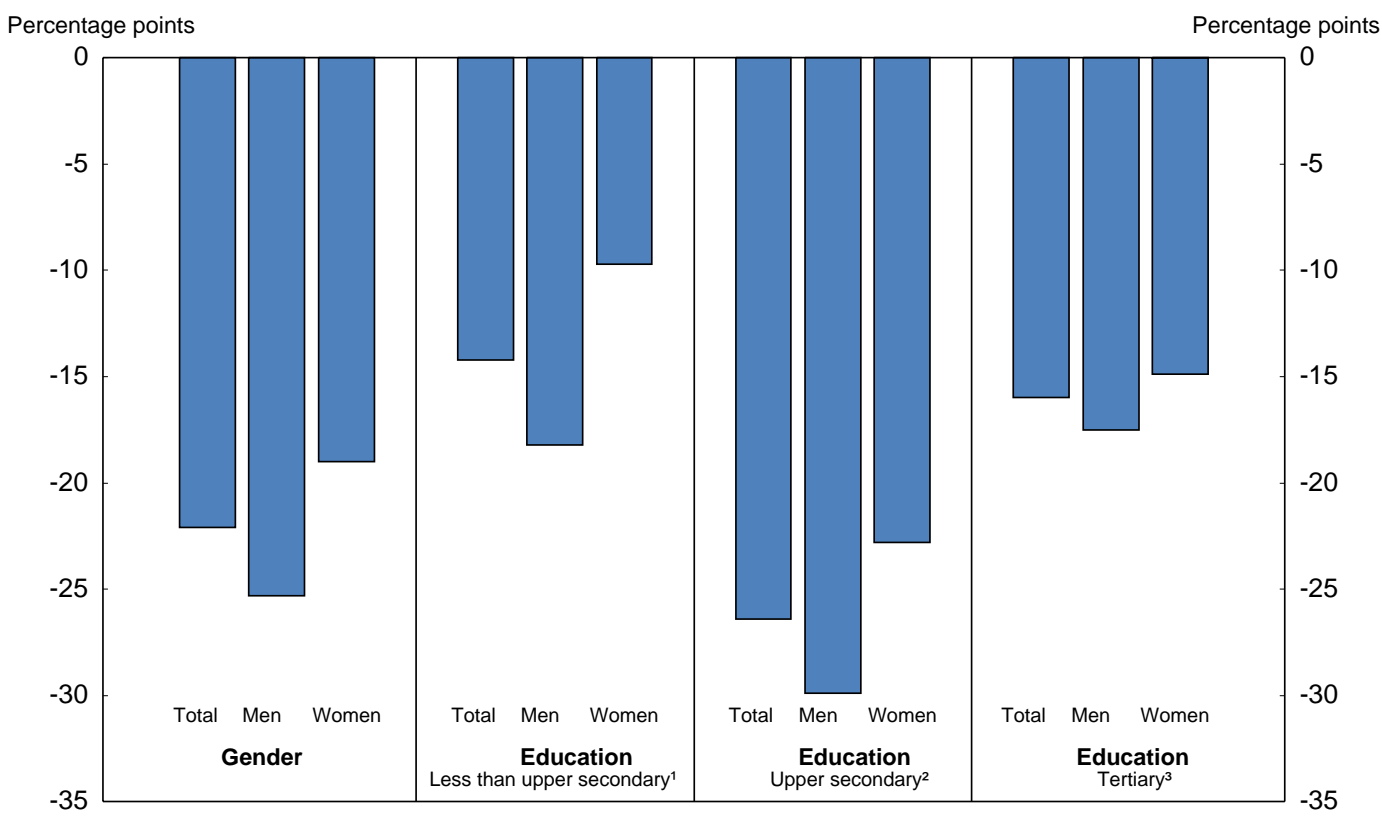

1. Pre-primary, primary and lower secondary education (levels $0-2$ ).

2. Upper secondary and post-secondary non-tertiary education (levels 3 and 4).

3. First and second stage of tertiary education (levels 5 and 6 ).

Source: Eurostat, European Union Labour Force Survey (EU-LFS). 
The decline in youth employment was concentrated in construction, a sector where the number of jobs collapsed from 60000 at the end of 2007 to only 5000 in the third quarter of 2012, and in services, which went from 160000 to 90000 positions during the same period (Figure 4). The sharpest fall has been among workers in craft and related trades, reflecting the collapse of construction activities. About $20 \%$ of the unemployed female and $10 \%$ of the unemployed male have a tertiary qualification (Figure 5).

Figure 4. Youth employment by industry and occupation

Number of employees in 2007 Q4 and 2013 Q1

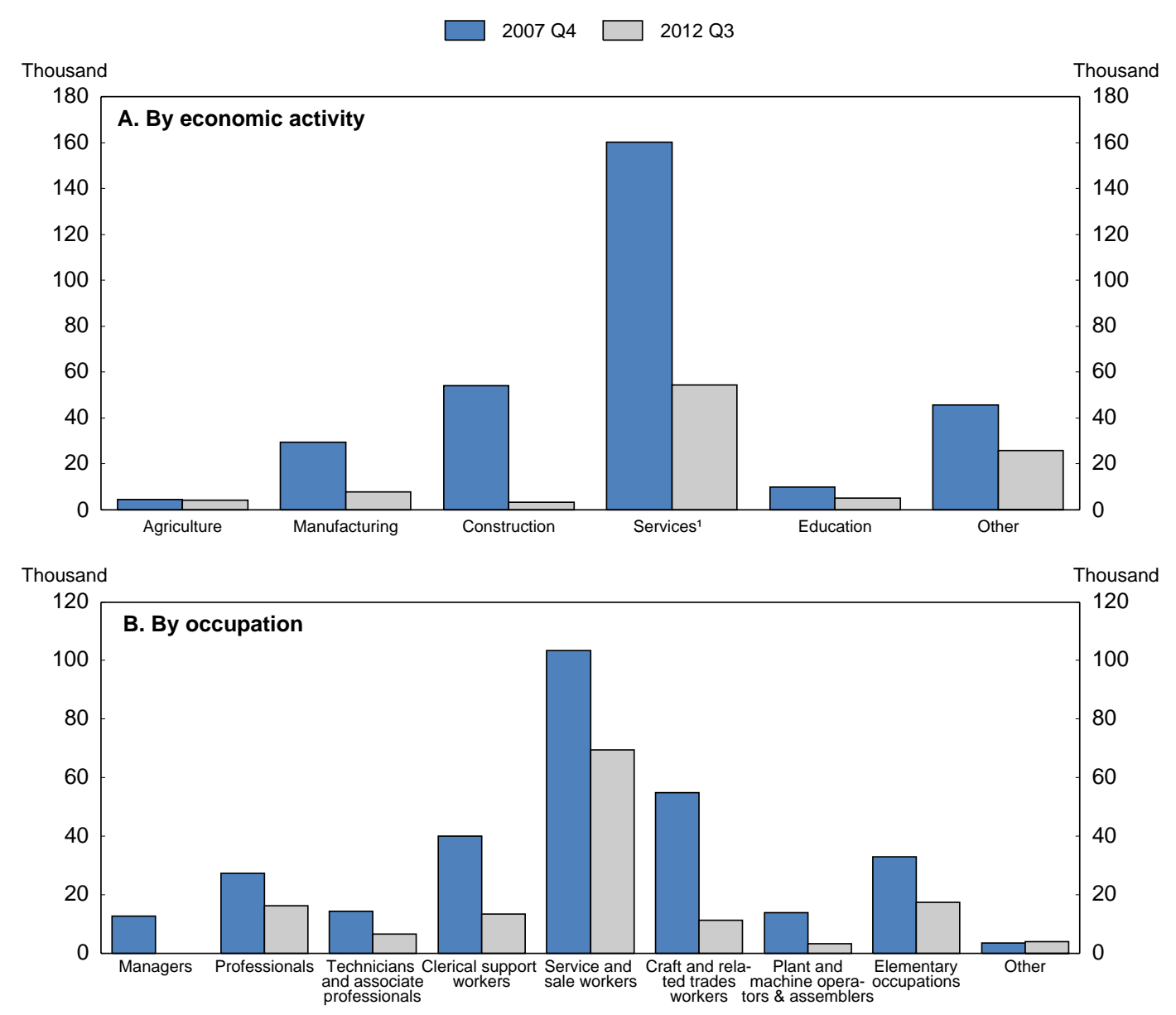

Note: Data refer to persons aged 15-24.

1. Service sector includes G-L sections of NACE rev.2. For 2007 Q4, data refer to G-K sections of NACE rev.1.

Source: Eurostat, European Union Labour Force Survey (EU-LFS).

Labour-market participation has fallen since the crisis, particularly among those aged 15-24 (Figure 6), who accounted for $90 \%$ of the overall decline in participation.

\section{Increasing emigration is a risk for long-term growth prospects}

As a consequence of the massive loss of employment and weak economic prospects, outward migration has sharply increased, reversing the pattern prior to the recession when Ireland was a net recipient of migration. Net emigration averaged $1.4 \%$ of the labour force in the period 2010-2012 and is expected to continue (one person out of two aged 18-24 was considering emigrating according to a poll by 
the National Youth Council of Ireland conducted in October 2012). Initially, after the bust, outward migration was mainly accounted for by workers from new EU member states. However, from 2010, emigration by Irish nationals surged and it now accounts for more than half of total emigration. Total emigration reached 87000 in the twelve months to April 2012 (CSO, 2012) and it has been concentrated in the 15-24 and 25-44 age groups. A notable change concerns destination. While the United Kingdom used to be the main destination followed by the United States and European Union countries, the majority are now moving to other countries such as Australia and Canada (Conefrey, 2013). Despite high levels of unemployment, poor labour market prospects and increasing emigration by Irish nationals, Ireland is still receiving significant immigration (around 50000 every year) (Gilmartin, 2012). This reflects the shortage of workers with the appropriate skills in some areas.

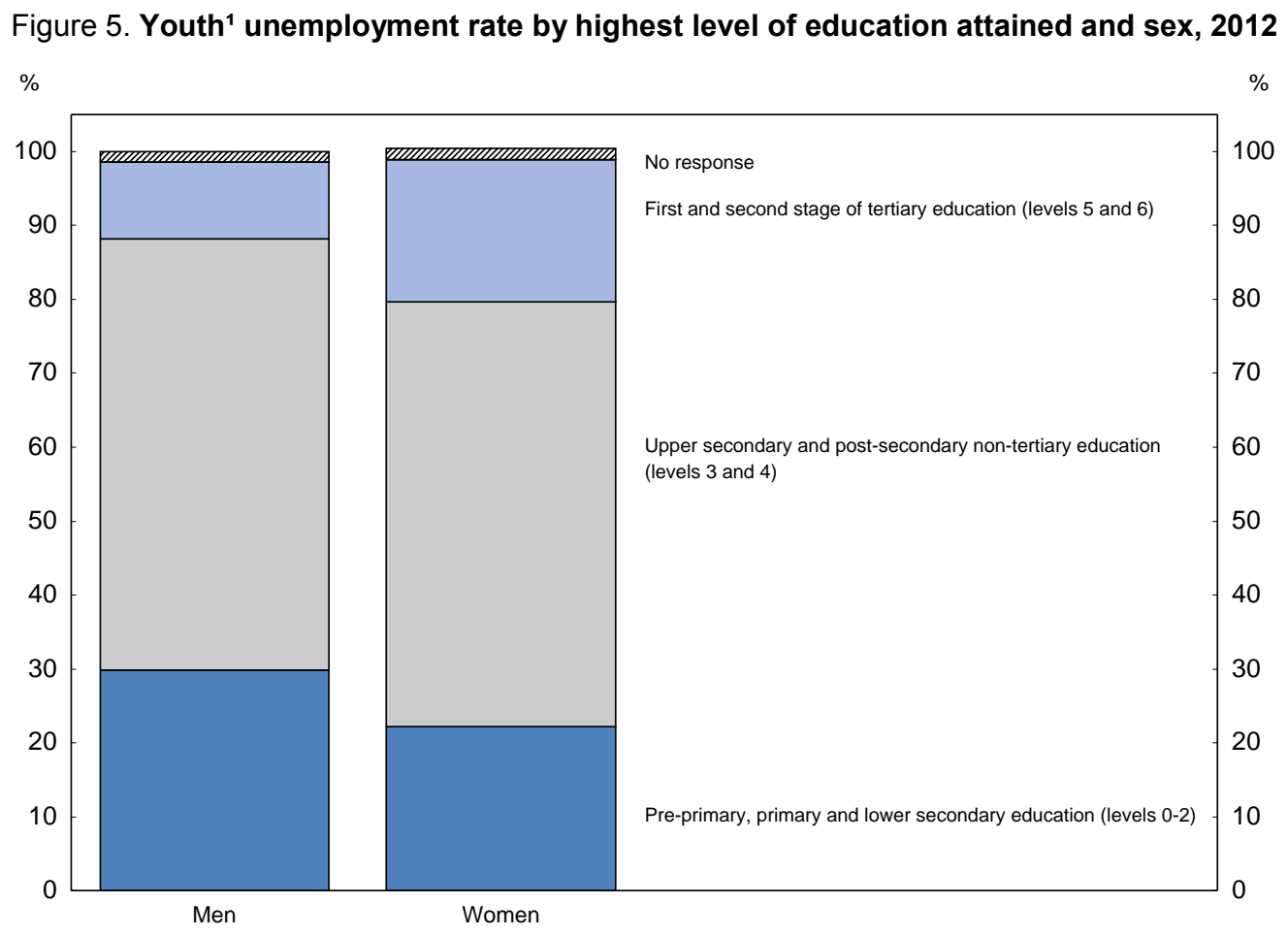

1. Persons aged $15-24$.

Source: Eurostat.

While emigration can be seen as a factor moderating the rise in unemployment, limiting scarring effects of being out of work and alleviating the pressure on public services, it entails significant risks for the long-term growth potential of the economy if the departures become permanent. This is not only because of the reduction in the size of the labour force, but also because emigration is concentrated in younger cohorts, which will exacerbate the impact of ageing. While Ireland had one of the largest youth cohorts in the OECD prior to the crisis, accounting for $16 \%$ of the population, this has fallen to $12 \%$, reflecting demographic trends and the rise in emigration (Figure 7).

In the mid-1990s, a period of high growth, Ireland was successful in reintegrating migrants, but international competition to attract workers with specialized skills has become fiercer and the automatic return of migrant workers, once the economy regains strength, should not be taken for granted. Mechanisms to better track emigrants and support their eventual return could reduce the risks of a permanent loss of valuable qualified workers from the labour force. 
Figure 6. Participation rates by age group, 2007 versus 2012

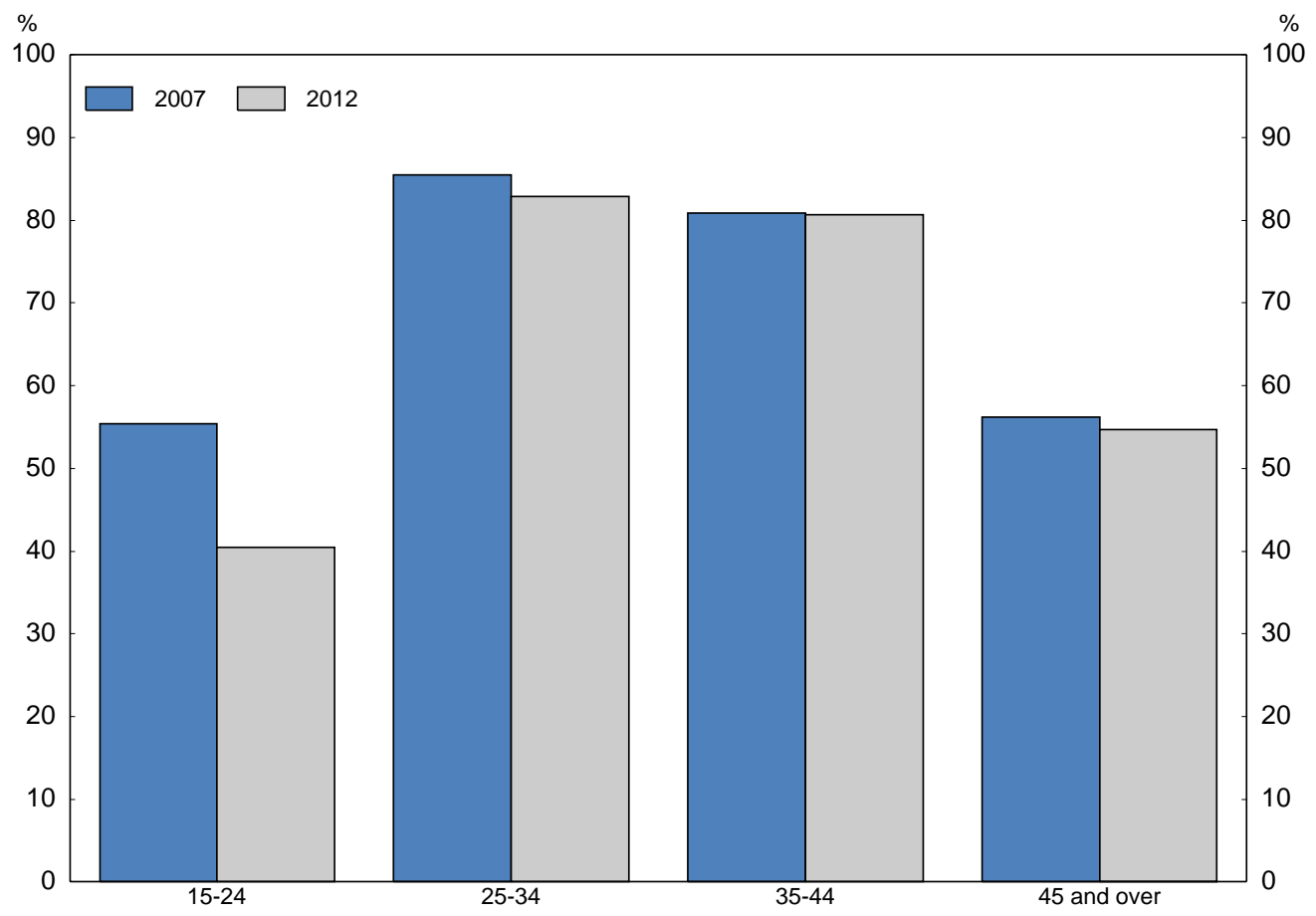

Source: Eurostat.

Figure 7. Youth ${ }^{1}$ cohort

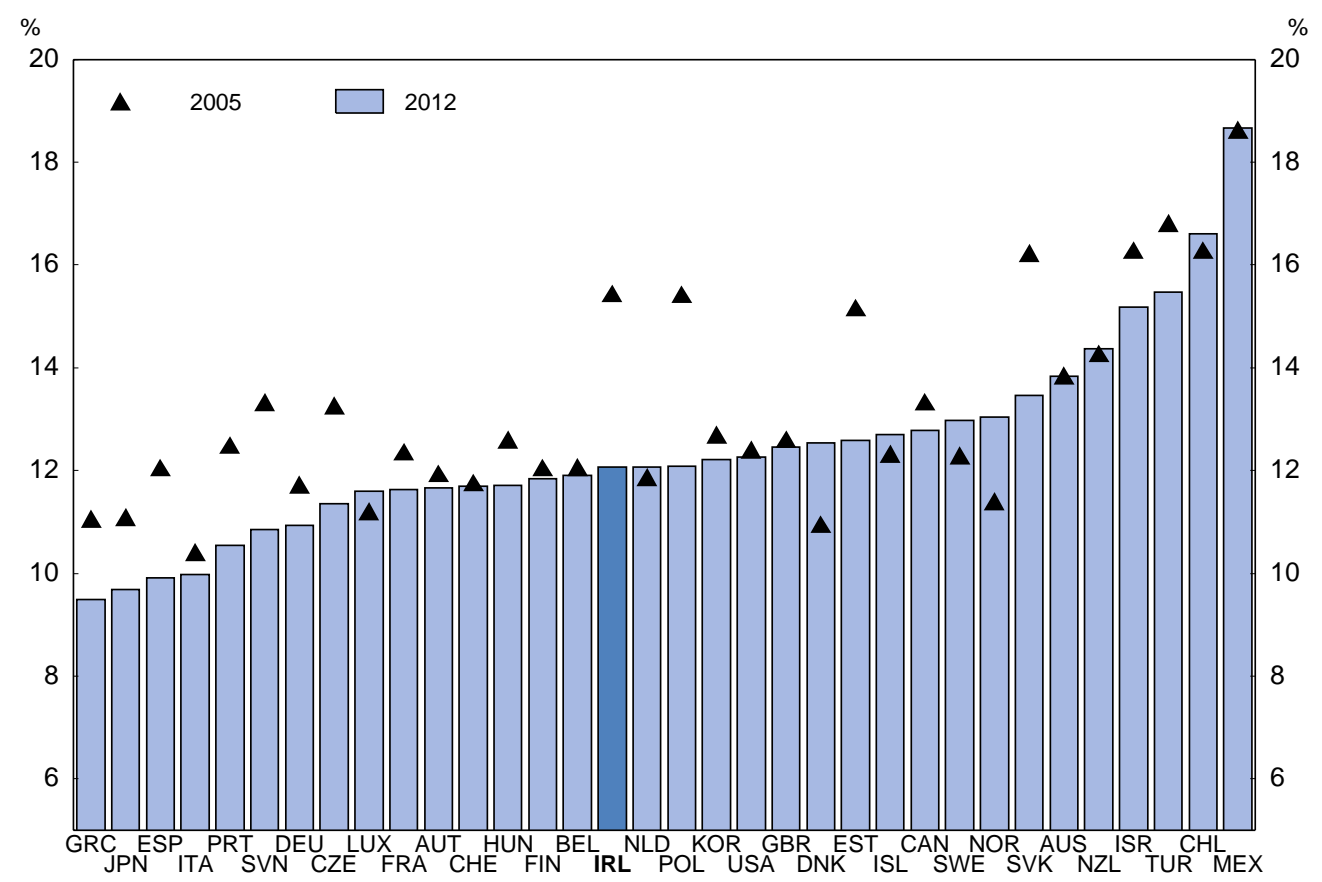

Note: For the year 2012, population data are estimated for many countries.

1. Persons aged 15-24.

Source: Eurostat. 


\section{Long-term unemployment, structural change, and the risks of a lost generation}

Long-term unemployment entails depreciation of human capital and may also be associated with poor health conditions and social distress (Arulampalam et al. 2001; Paul and Moser, 2009; Puig-Barrachina, 2011) (more below). This is a matter of concern because the proportion of young people who are long-term unemployed has increased from $21 \%$ in 2007 to close to $50 \%$ in 2012 (Figure 8) and they face poor probability of exiting from unemployment (Figure 9). While before the crisis the probabilities of youth reentering employment was similar in Ireland, the United Kingdom and the Euro area, the prospects in Ireland are now the worst. The exit prospects have deteriorated in overall terms, but those who have been unemployed for more than one year are the ones who had the largest decline in the probability of exiting unemployment. The probability of exiting unemployment for young workers unemployed for less than twelve months is $65 \%$, but it falls to $40 \%$ for those unemployed for longer than a year.

Prior to the recession, the duration of an earlier unemployment spell was found to be key to explaining the risk of remaining unemployed (Kelly et al., 2012). The recession has increased this negative effect of past unemployment spells, with the proportion of those making a successful return to work having fallen from $38 \%$ in 2006 to only $17 \%$ in 2011, while the proportion of youth remaining continuously unemployed increasing from $37 \%$ to $52 \%$ during the same period and the share of those drifting into inactivity increasing from $25 \%$ to $31 \%$ (Kelly et al. 2013). Those with an unemployment period lasting more than three months are significantly less likely to return to work. There are also significant differences pre and post-recession in other factors such as education level or age (discussed below).

Figure 8. Share of long-term unemployment in total youth ${ }^{1}$ unemployment, 2007 versus 2012

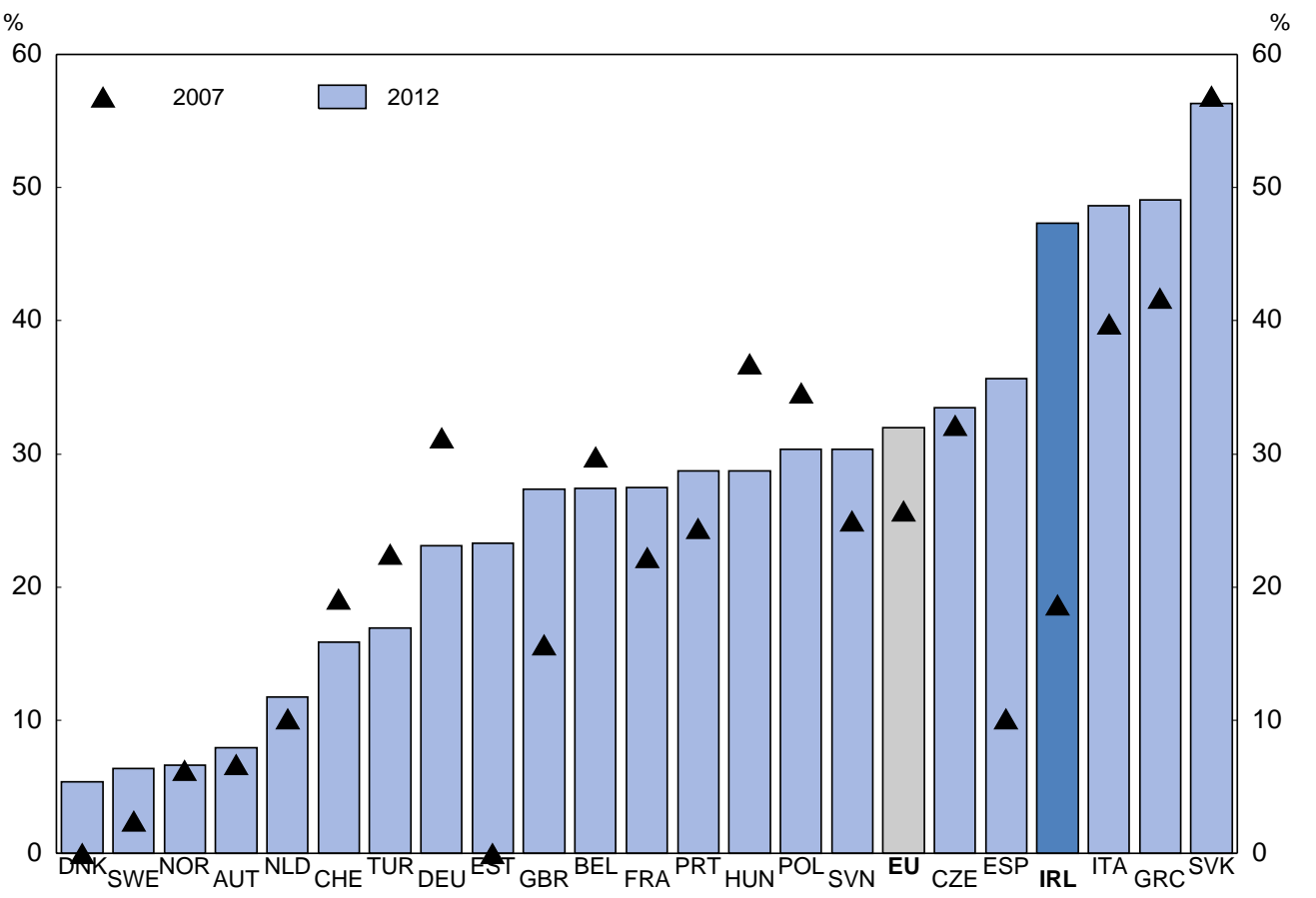

1. Persons aged 15-24.

Source: Eurostat. 
Figure 9. Evolution of unemployment-exit probabilities

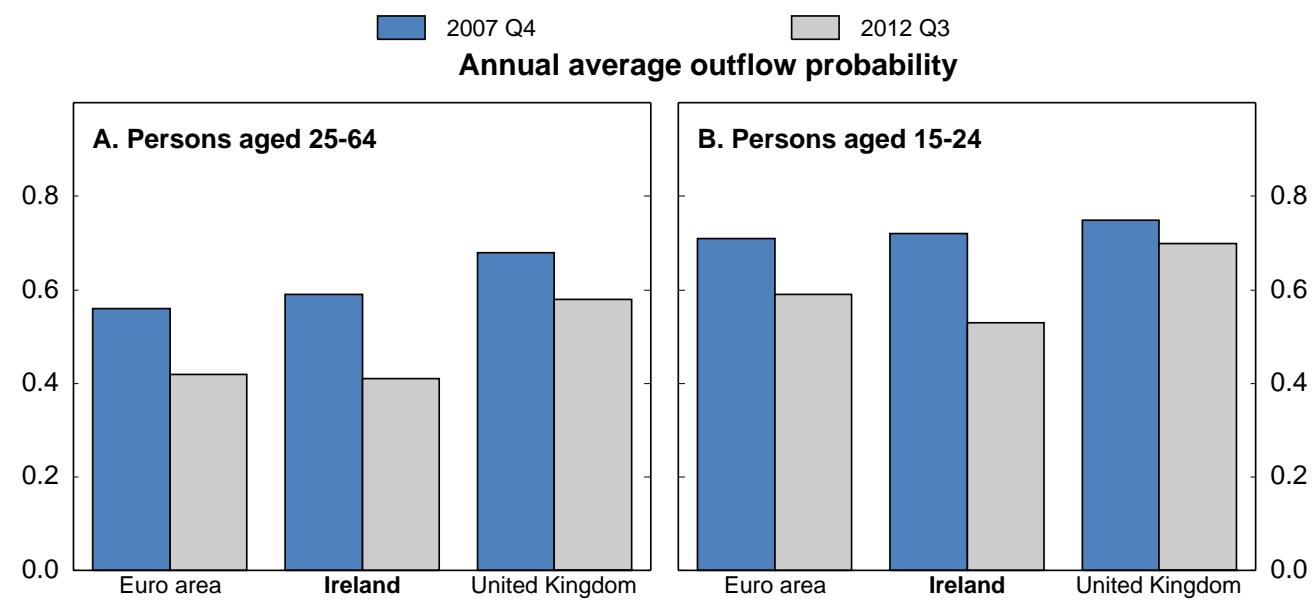

Annual outflow of those unemployed less than 12 months

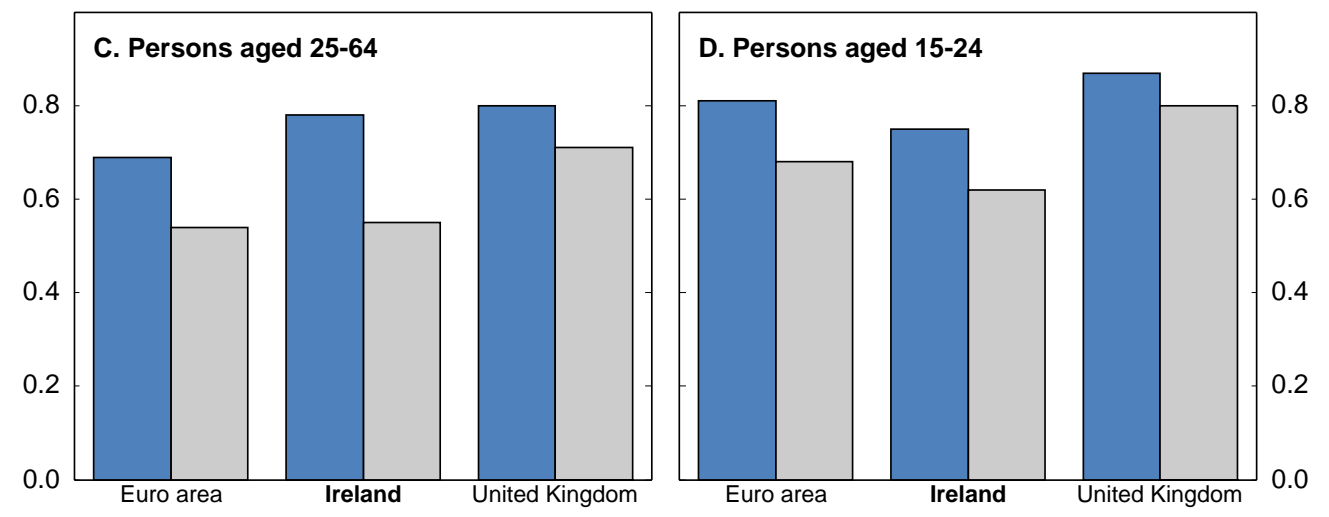

Annual outflow of those unemployed for 12 months or more

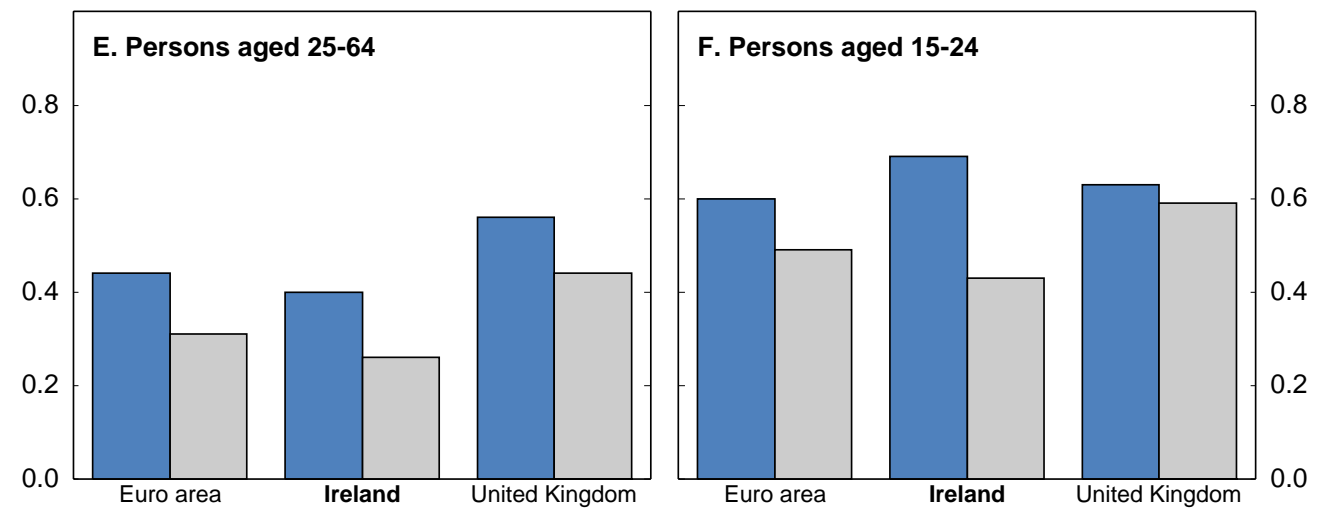

Note: Euro area refers to the 17 countries. The outflow probability for those unemployed less than 12 months (for those unemployed for 12 months or more) is calculated as one minus the ratio of the number of unemployed with a duration of 12-24 months (number of unemployed with a duration of 24 months or more) over the number of persons unemployed for less than 12 months (number of persons unemployed for 12 months or more) one year earlier.

Source: Own calculations based on Eurostat data. 
Youth employment is generally more sensitive than adult employment to business-cycle conditions (e.g. Bell and Blanchflower, 2011), and particularly so in Ireland (OECD, 2008b). Such sensitivity is greater for the 15-19 age cohort and then declines progressively with age. This is explained by the higher incidence of temporary contracts among young workers, and in the case of Ireland it is also due to a higher concentration of youth jobs in highly cyclical sectors, such as the construction sector. The Irish economy is not expected to return to the exuberant pace of growth of the decade preceding the crisis, particularly the housing and property market weighed down mired by excessive supply, so the economy may not generate significant many low and medium-skilled jobs. Employment is more likely to be found in the exporting high-tech sector, where high-skilled services play a greater role. The new jobs are already concentrated in services such as information and communication, professional, and scientific and technical activities (CSO, 2013).

Against this background, young people who have been unemployed for many months and do not have the types of skills demanded by fast-rising sectors risk become increasingly detached from the labour market. Empirical evidence indicates that, while prior to the recession unemployed youth aged 20 to 24 were more likely to find a work compare to those aged 15-19, the opposite is observed post-recession (Kelly et al., 2013). This could indicate that employers may have a preference for younger workers who have a lower minimum wage and shorter spells of unemployment to the detriment of older youth that have been out of work for a longer period, and highlights the risks of a cohort of young workers getting excluded from emerging job opportunities. This calls for important policy action to foster labour re-allocation via active labour market policies, particularly training.

\section{Disadvantaged youth}

Entering the labour market at the current juncture is especially challenging for disadvantaged youth such school dropouts, young individuals from immigrant background, those living in workless households and those suffering from disabilities. The proportion of those who are at risk of losing contact with the labour market, youth not in education or employment (NEET), is higher in Ireland than in most other OECD countries, and has seen a sharp increase from 2007 to 2011 (Figure 10). Of significant concern is the rate of youth not in education and not in the labour force (i.e. inactive youth), which was already high prior to the crisis $(\mathrm{OECD}, 2012)$. An additional concern is that Ireland has one of the highest NEET rates among those aged 15-19. Being away from the labour market and from the educational system at such an early age is likely to have long-lasting damaging consequences. 
Figure 10. NEET rates among youth ${ }^{1}$ in European countries
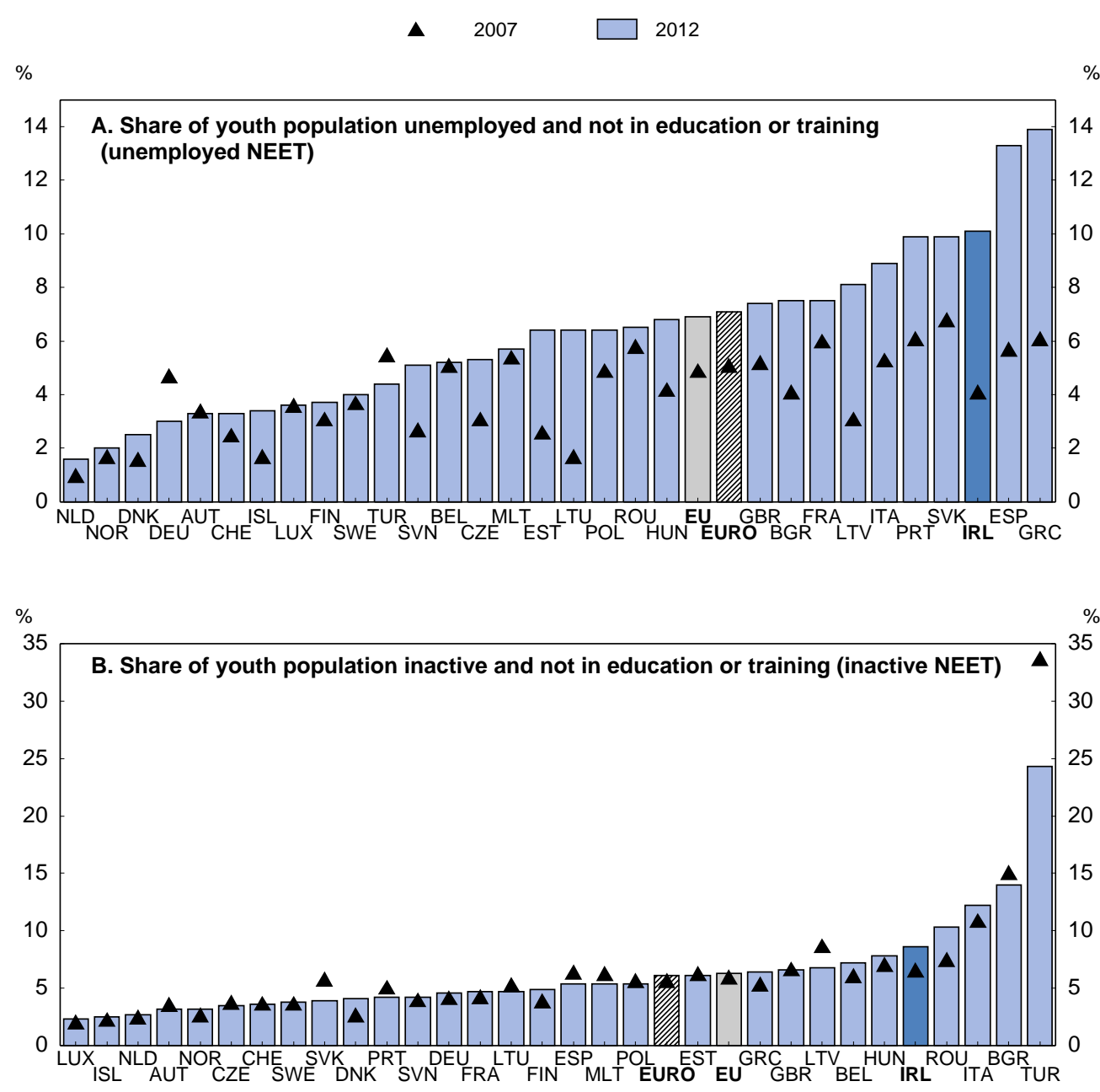

1. Persons aged $15-24$.

Source: Eurostat.

Employment losses have hit non-Irish nationals four times more than Irish nationals (McGinnity et al., 2011). While young non-Irish had slightly better prospects than young Irish before the recession, they now seem to be having more difficulties in exiting unemployment than Irish nationals (Kelly et al., 2013). The second generation of immigrants, contrary to findings in other European countries, seems well integrated and there is no significant evidence of school segregation (Byrne, 2010). This is mainly due to the high geographical dispersion of the immigrant population and the wide variety of nationalities present in Ireland. 
Figure 11. NEET by age group, 2012
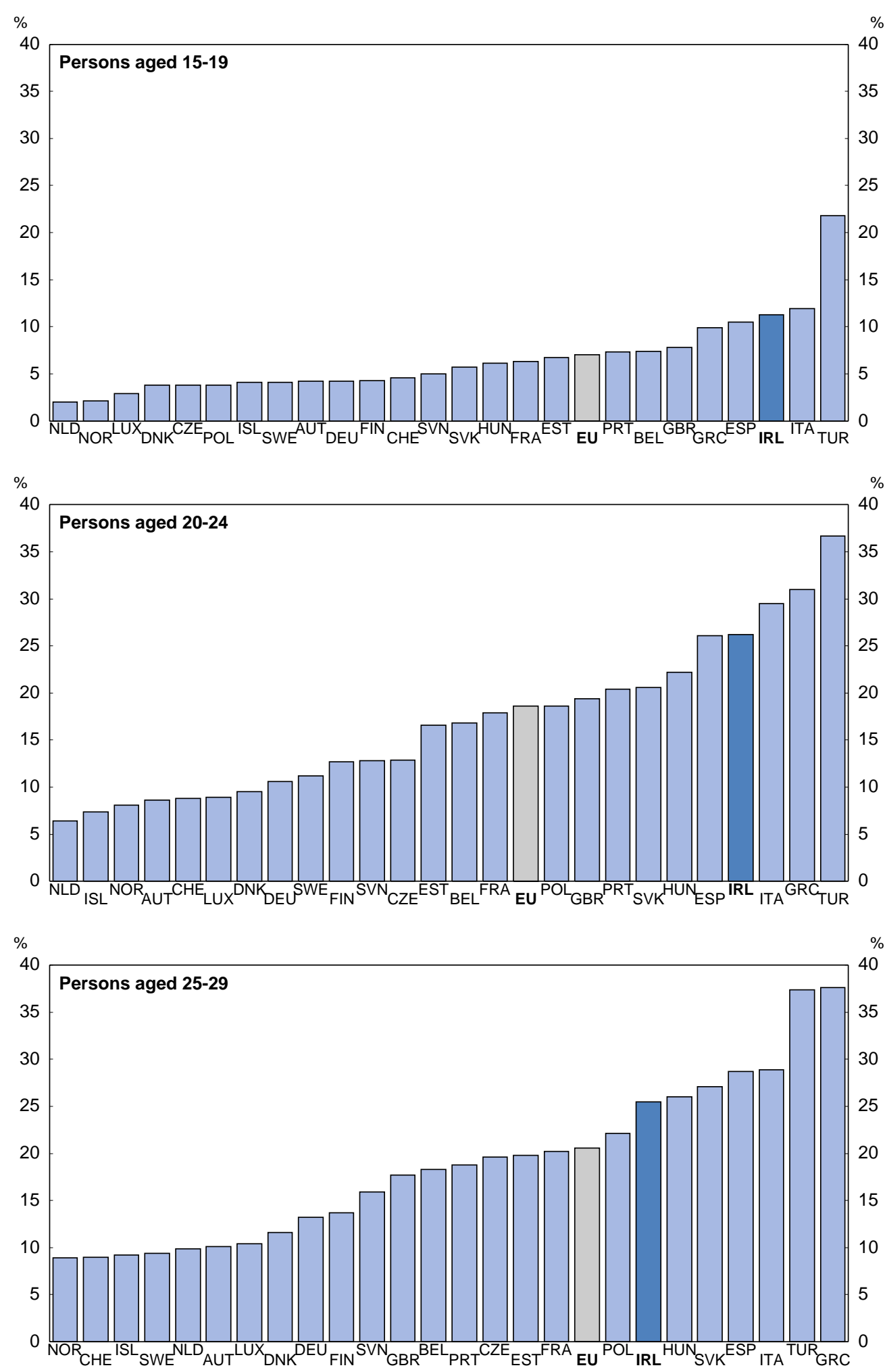

Source: Eurostat. 
Ireland's welfare system has provided an effective cushion during the crisis. Nevertheless, the risk-ofpoverty of those between 16 and 24 years old is above the EU average (Figure 12) and has increased from $26 \%$ in 2007 to $40 \%$ in 2011 . The same indicator for individuals below 16 years had a similar increase in the same period. These developments highlight the pressing need for helping youth to step into the labour market as the best way to escape poverty and social exclusion.

Figure 12. Young people at risk of poverty or social exclusion

As a percentage of total population
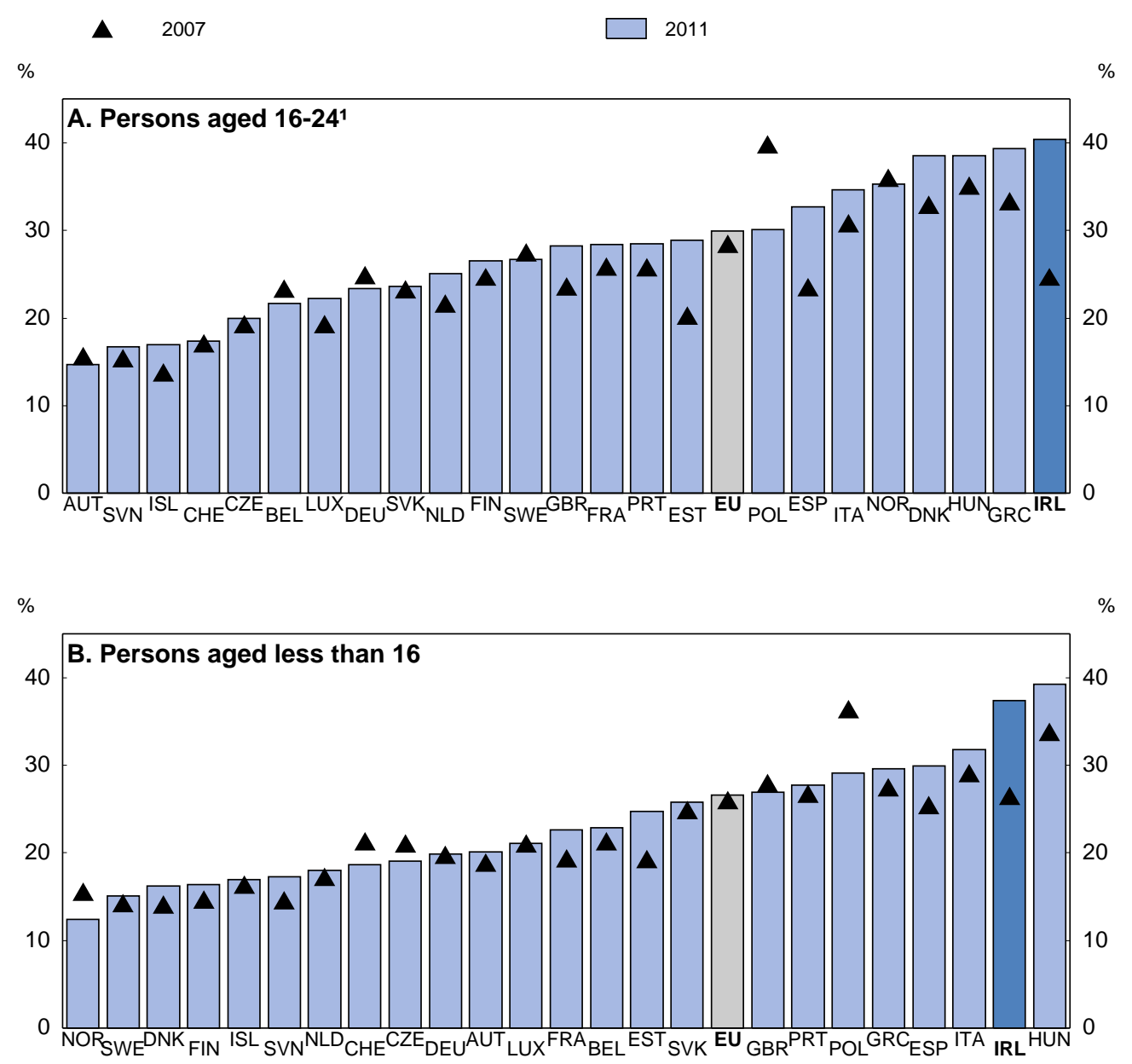

1. Caution should be used in cross-country comparisons due to differences in the propensity of students to live away from home.

Source: Eurostat.

An increase in the long-term unemployment rate and dependency on social welfare has been associated with a rise in mental health issues, drug and alcohol abuse, and an increase in criminal behaviour among young people. However, to date the consumption of alcohol, tobacco, cannabis and other drugs by Irish youth does not stand out in international perspective (ESPAD, 2012) and there is no significant evidence of an increase in youth crime. Nevertheless, Ireland has one of the highest rates of suicide among youth in Europe, specially for male youth (Figure 13), and in historical perspective, a link between the unemployment rate and the male suicide rate in younger age groups has been established for Ireland (Walsh, 2012). This demands an increased focus on prevention policies. 
Figure 13. Total suicide and intentional self-harm death rates per 100000 for 15-29 years olds

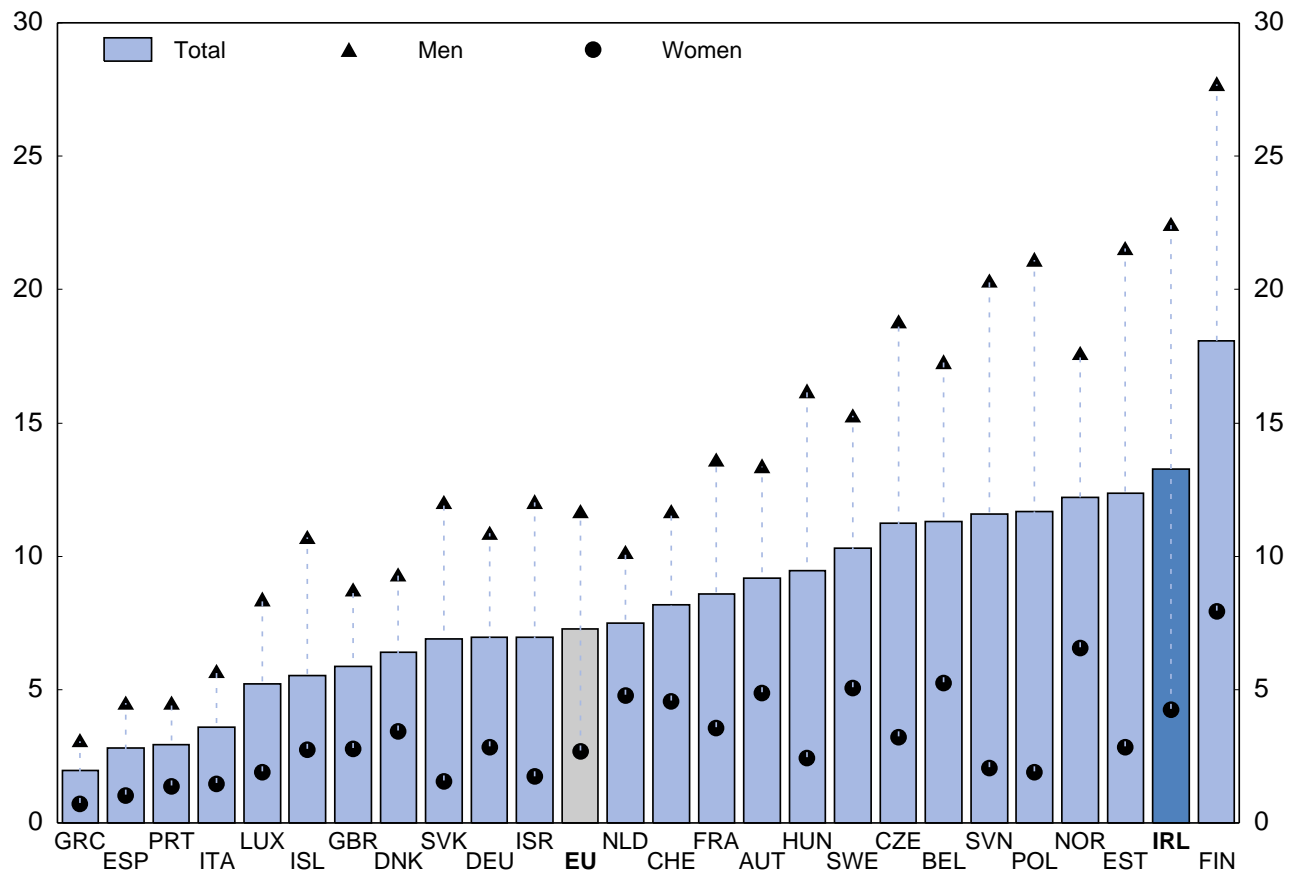

Note: 2011 or latest year available.

Source: European Mortality database, August 2012.

\section{Ensuring active labour market and benefit policies better support young unemployed}

The risk of a "lost generation" calls for decisive intervention in the youth labour market. Given high and persistent unemployment rates among young workers, activation policies are paramount to limiting scarring effects. In the short-term, weak economic growth and labour demand will limit the decline in unemployment. However, it is important to maintain youth connected to the labour market so that they can return to work when the recovery strengthens. To that aim, implementing effective active labour market programmes (ALMPs) well targeted at the specific needs of youth is key. ALMPs are essential for youth even in times of buoyant employment creation. Young workers may be less efficient in job search activities than adults. They are also likely to have fewer contacts and less experience of finding work, placing them at a relative disadvantage compared to adults (Bell and Blanchflower, 2011). Therefore employment assistance and support services provided by the public employment services can play a vital role.

Ireland devotes significant fiscal resources to labour-market policies by international standards (Figure 14). However, a large proportion of this spending has gone into passive programmes, even before the bust, and some of the spending on active measures, such as Community employment, had little effect in helping participants to re-enter the labour market (more below). In a context of tight fiscal and budgetary constraints, the emphasis should be on implementing cost-effective policies found to increase the employability of participants. In international perspective, job search assistance seems to yield favourable results (Martin, 2000; Kluve, 2006; Card et al. 2010), and in the Irish context it also has been found to increase the probability of returning to work (McGuinness et al., 2011). Direct public sector employment programmes are found to be less effective both internationally (Kluve, 2006; Card et al. 2010) and in Ireland (McGuinness et al., 2011). Training programmes are associated with positive medium-term impacts 
(Card et al. 2010). In Ireland those who participated in training were found to be less likely to be unemployed although the impact differed according to the type and duration of the training received (McGuinness et al., 2011a) (more below).

Comparing the pre-crisis participation of youth in active and passive labour market schemes across countries highlights that participation in active measures, such as training or employment incentives, was low in international perspective (Figure 15). By contrast, participation in passive measures, aimed at income support, was already relatively high in 2007. Post-crisis, the percentage of youth supported by passive measures increased from $10 \%$ in 2007 to more than $30 \%$ of the youth labour force, the highest rate in the EU and more than triple the EU average. Participation in active labour market programmes also increased but remained clearly below the EU average.

Figure 14. Public expenditure on Labour Market Programmes: main categories

As a percentage of GDP

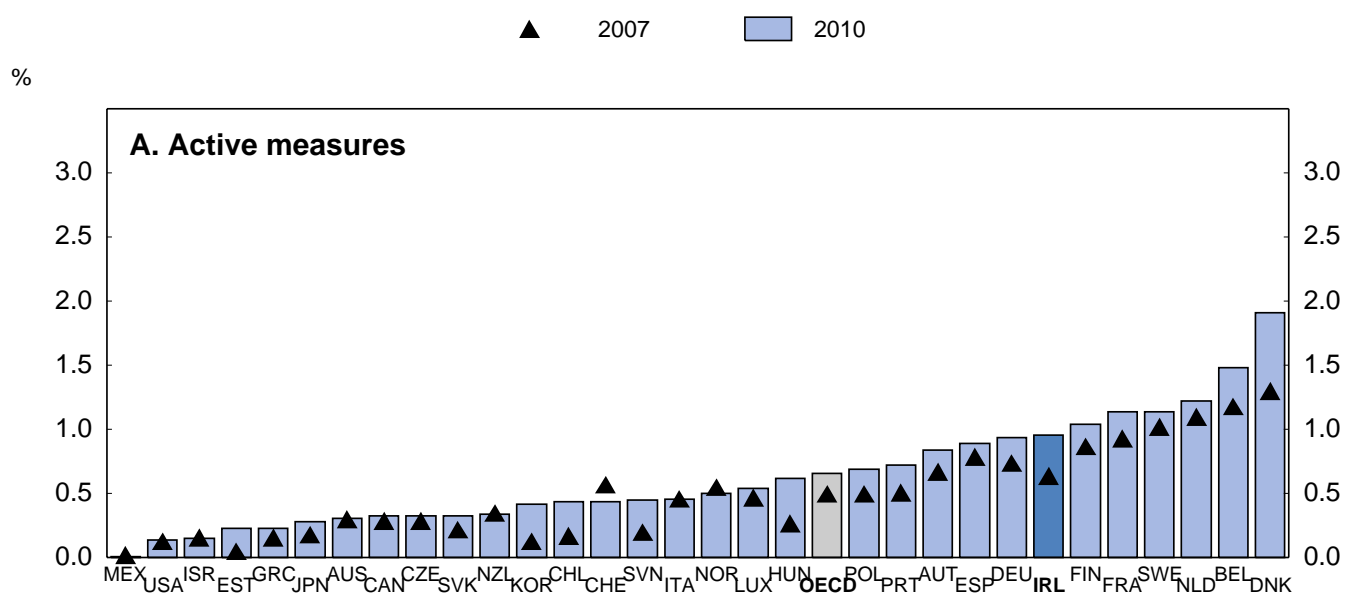

$\%$

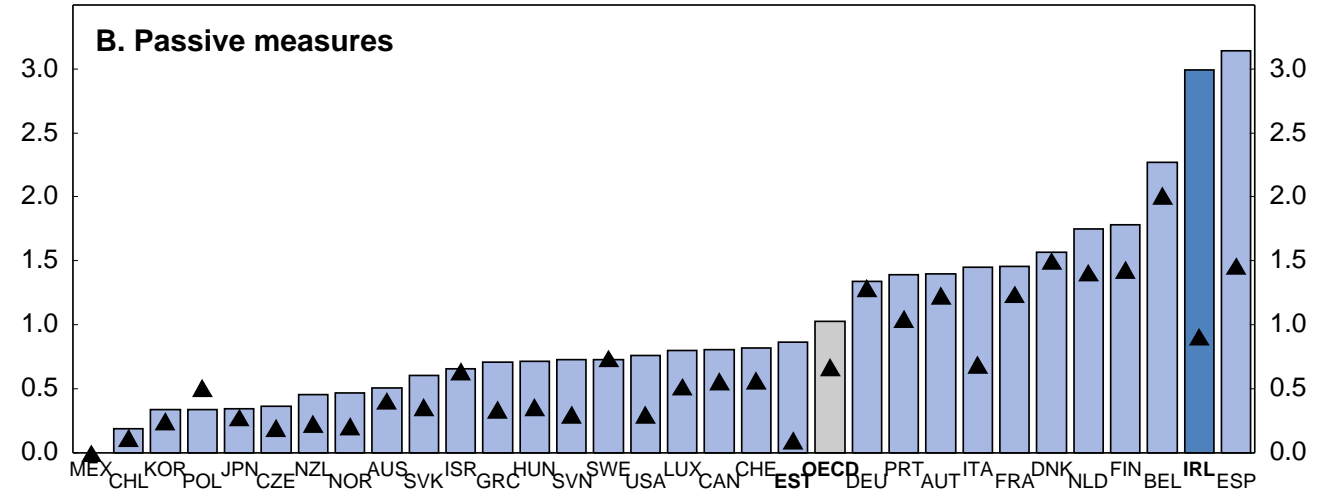

Note: Active measures refer to categories 1-7 of the OECD/Eurostat Labour Market Programme database. They include PES and administration (placement and related services, benefit administration), training, employment incentives, supported employment and rehabilitation, direct job creation and start-up incentives. Passive measures refer to categories 8-9 and include out-of-work income maintenance and support and early retirement. 2 . Include out-of-work income maintenance and support and early retirement.

Source: OECD/Eurostat Labour Market Programmes database. 
Figure 15. Young ${ }^{1}$ participants on Labour Market Programmes: main measures

As a percentage of the labour force in the same age group
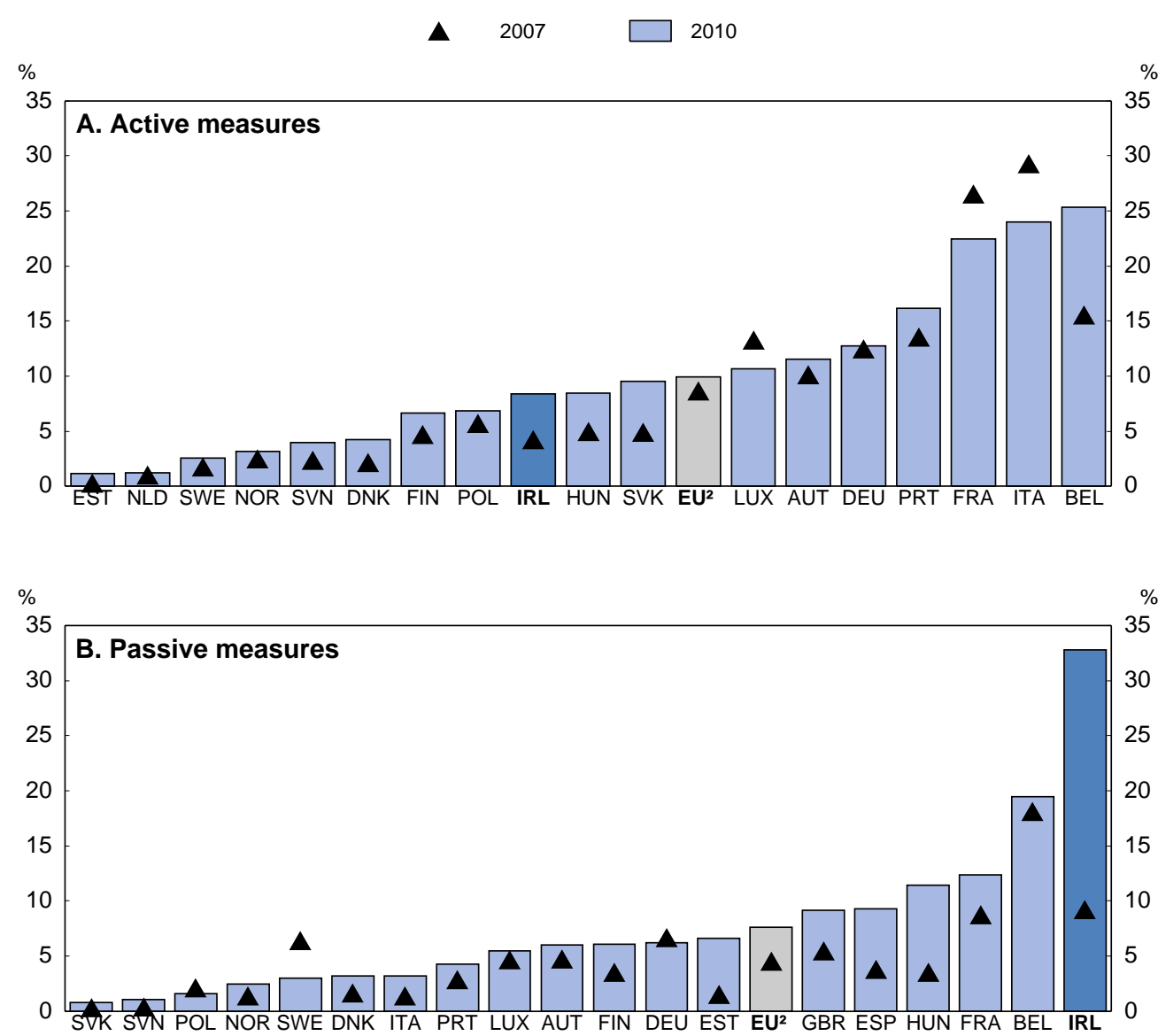

Note: Active measures refer to categories 2-7 of the OECD/Eurostat Labour Market Programme database and include training, job rotation and job sharing, employment incentives, supported employment and rehabilitation, direct job creation and start-up incentives. Passive measures refer to categories 8-9 and include out-of-work income maintenance and support and early retirement.

1. Persons aged $15-24$.

2. The EU area is the simple average of countries for which data are available.

Source: OECD/Eurostat Labour Market programmes database.

Support for youth via passive schemes is needed to avert poverty risk and social exclusion. Passive measures include out-of-work income maintenance and support measures such as the job seekers benefits (JSB) and job seekers allowances (JSA). JSB are taxable weekly payments to persons over 18 who are out of work and have accumulated enough social security contributions. They were paid for 15 months in the 2000s, were reduced to 12 months in 2008 and, as of April 2013, were reduced again to 9 or 6 months depending on the level of social security contributions paid. Those not qualifying for JSB, or those who have used it up, can apply for the JSA, which is means tested. Youth unemployed retain their full JSB payment if they participate in a training programme. As of 2013, the maximum JSB payable to youth was reduced from 188 EUR per week to 100 EUR for those under 22 years and to 144 EUR for those aged 22-24, with a rate of 160 EUR for those participating in certain education and training programmes. These changes aim at boosting work incentives and encouraging participation in training activities. 
As the economic recovery strengthens and employment prospects improve, the emphasis of labour market policies should be re-geared towards more active measures for youth to the detriment of passive schemes. It will be increasingly important to ensure that income support is subject to stricter and rigorous mutual obligation regimes. In an-innovation led economy, such as the one Ireland strives to become, it is essential to foster continuous labour reallocation across sectors and firms through effective active labour market policies.

The Irish authorities launched Pathways to Work (PTW) in February 2012, a major initiative to foster engagement with the unemployed, enhance activation and incentives to take-up opportunities, strengthen links with employers, and reform institutions to improve the services delivered to the unemployed (Box 1). The new activation regime is stricter than the previous one, where the waiting period to receive benefit payment and employment services was around 4 weeks and the first intensive job-counselling interview with a caseworker was typically only offered after three months on the live register. The number of sanctions imposed was also low prior to the reform. PTW has introduced a new stricter procedure for sanctions, although the actual number of people sanctioned remains low in international comparison, reflecting the high compliance so far. In certain respects, such as job-search monitoring, the regime remains weaker in comparison with other OECD countries such as the United Kingdom or Australia where a minimum of job-search actions need to be reported every two weeks.

\section{Box 1. Pathways to work}

The Pathways to Work policy and the establishment of the new Integrated National Employment and Entitlement Service (Intreo) service aims at establishing an enhanced engagement between the employment and income support services and the unemployed, including those under the age of 25. Intreo services are delivered via one-stop-shops where job-placement and benefit administration are integrated in a single delivery unit. The new policy is underpinned by five core principles (Pathways to Work, 2012):

- $\quad$ More regular and ongoing engagement with the unemployed.

- Greater targeting of activation places and opportunities.

- Incentivising the take up of opportunities by the unemployed.

- Creating and enhancing relations with employers through incentivising the provision of opportunities for people who are unemployed.

- $\quad$ Reforming institutions to deliver better services to the unemployed.

The first stage in the process is the client registration both for welfare entitlements and employment services. As part of the registration process the client completes a profile questionnaire to enable a case worker to assess their Probability of Exit (PEX) from unemployment and develop a personal progression plan. Depending on the outcome of the assessment, the progression plan will offer a level of engagement with the employment services. For example, clients with a high PEX rating will be encouraged and helped to search for employment. Clients with a mid-point PEX rating, and those with a high-PEX rating but still unemployed after three months, will be invited to participate in group sessions where they will be provided with guidance on how to improve their job search activities and also on the training and development opportunities available to them to improve their employment prospects. Clients with a low-PEX rating and all those unemployed after 12 months will receive intensive one-to-one support from an employment advisor.

PTW improves the delivery of ALMPs in Ireland and it is in line with previous OECD recommendations in this area (OECD, 2011, Grubb et al. 2009). However, the pace of reform implementation is slow and the number and scope of unemployed workers covered by the enhanced Intreo services remains low considering the pressing needs for activating the jobless population. Previous OECD studies stressed the number of people in employment offices providing job-search assistance and monitoring, relative to the numbers of unemployed workers in the economy, were well below that in other 
advanced economies. These resource constraints are more acute nowadays given the growing number of unemployed. At present, each case worker oversees approximately 800 jobseekers, which is high by international standards. Youth require a more intense and comprehensive job-search assistance and counselling and are therefore likely to be seriously affected by the insufficient number of caseworkers. A major concern is also that the long-term unemployed are not covered by the enhanced Intreo services and have not yet even received the one-to-one interview where the needs of the individual are assessed by a caseworker and the personalised action plan is drawn-up and initiated. To reach more long-term unemployed persons, the government is considering contracting out activation to private providers. Experiences in other countries suggest that, if properly designed, contracting out can make a positive contribution but there are difficulties in implementing it in an effective way. In addition, empirical research, focused on large-scale job seeker assistance program targeted at young graduates in France, suggests that contracting out may create a substitution effect. Job seekers assisted by external providers are more likely to get a job, but at the expense of other unemployed workers with whom they compete in the labour market and did not receive the external assistance, and there is no significant net effect on reducing unemployment (Crépon et al, 2013). Further delaying tackling the long-term component of youth unemployment with an effective activation regime increases the risk of a lost generation. The number of caseworkers in Intreo should be further increased as soon as possible, through further internal redeployment, to provide long-term unemployment with appropriate engagement and support.

\section{The government needs a more strategic approach to youth unemployment}

A comprehensive national strategy to tackle the very high unemployment rates among youth is lacking. Youth policy is fragmented, with several Government departments taking individual action. A more coordinated and tailored approach to the youth unemployment problem is required, including profiling and a reallocation of resources towards schemes with greater activation success for youth based on rigorous evaluation and a youth guarantee.

Good programme targeting is vital for youth because their profiles and their needs may differ significantly. The introduction of the profiling model to define targeted pathways to work depending on the characteristics of the individual is a decisive step forward. However, the Irish economy is undergoing profound structural changes and recent evidence indicates that the determinants of unemployment have changed significantly (Kelly et al., 2013). In line with practices in other countries such as Australia (Lipp, 2005), the profiling model needs to be continuously assessed and updated to take into account the new economic conditions. The model is currently being applied to jobseekers who get registered in the employment offices. There is also a pressing need to define targeted policies for youth neither in education nor in the labour force or those suffering from disabilities. The profiling model should therefore be enhanced in order to incorporate relevant characteristics for those individuals.

Outreach programmes together with early intervention are key for youth. For that it is essential to ensure appropriate co-operation between the public employment services and the education system to reach youth as soon as possible (OECD, 2010). The focus should be on assessing whether they have relevant qualifications, and in case they do not have them, they should return to training. For those considered jobready the most cost-effective ALMP is to provide them with a job-search assistance "package" as early as possible. The "package" should include not only aspects related with job-search techniques such as how to write a resume but should also incorporate guidance concerning geographical mobility or housing assistance. For those with more important problems entering the labour market, the "package" could include adult mentoring, work experience and remedial education (OECD, 2010). Reading and writing tests should be taken as early as possible to detect potential obstacles in these areas, which have been associated with risk of long-term unemployment (Kelly et al. 2011). Courses should be made available for those who do not meet acceptable literacy standards before progressing to other ALMPs. 
The Department of Social Protection has been increasing spending on ALMPs despite intense fiscal constraints (Table 1). However, programmes that account for more than half of spending (direct job creation programmes, such as Community employment) have very little youth participation. The main programmes potentially aimed at youth are the internship schemes, accounting for $8 \%$ of the total spending, and Back to Education Allowance, which accounts for $23 \%$ of the spending. The fourth main scheme, with $16 \%$ of the budget, aims to supporting self-employment and also has few young participants (more below). In addition, the two programmes with the largest participation by youth, accounting for $31 \%$ of the total, are not exclusively targeted at youth and also have significant adult participation.

Table 1. Trends in Department of Social Protection employment support schemes (EUR million)

\begin{tabular}{|c|c|c|c|c|c|}
\hline & Nature & 2007 & 2010 & 2011 & 2012 \\
\hline Community Employment Programme & work-programme & 357.5 & 368.3 & 356.7 & 315.2 \\
\hline $\begin{array}{l}\text { Rural Social Scheme } \\
\text { Tús - Community Work Placement }\end{array}$ & work-programme & 47.8 & 46 & 46.1 & 45.7 \\
\hline Scheme & work-programme & 0 & 0 & 30 & 84 \\
\hline Job Initiative & work-programme & 40 & 30.2 & 28.5 & 27.2 \\
\hline Back to Work Allowance & $\begin{array}{l}\text { Self- } \\
\text { entrepreneurship }\end{array}$ & 71 & 87.9 & 91.5 & 137.9 \\
\hline JobBridge & internship & 0 & 0 & 20 & 65.8 \\
\hline Back to Education Allowance & training & 64.1 & 179.8 & 198.8 & 183 \\
\hline Other programmes reviewed (est.) & & 10 & 16 & 17.3 & 15 \\
\hline Total above & & 590.4 & 728.2 & 788.9 & 873.81 \\
\hline
\end{tabular}

In a context of structural change the ability to adapt to labour market needs is key for designing successful and efficient ALMPs. Allocating resources to those programmes that prove effective and efficient in improving the labour force performance of participants and abandoning those that do not help the unemployed return to work is vital to get value for money. It also enables the authorities to establish targets for government agencies and private sector service providers. All this calls for a systematic, independent, and rigorous programme evaluations and performance measurement. Evaluations should be able to isolate the effect of the programme from the outcome that would have been achieved without programme participation. This can be done either via experimental evaluations or quasi-experimental evaluations based on statistical techniques. Evaluation culture is well-established in North-America and the United Kingdom, and is progressing in some European countries such as the Nordic countries and the Netherlands. Ireland should also take decisive steps in this field. These steps should include greater political commitment to evidence based policy making (Johnston, 2006) and establishing legal requirements for evaluation including its funding. Linked to the rigorous evaluation, sunset clauses should systematically be introduced, implying a regular review of the need for policies and schemes.

When allocating resources to different schemes, preference should be given to those schemes that are effective in integrating participants in the labour market, to the detriment of those schemes with a poor performance in increasing the employability of participants, such as Community employment (O'Connell et al., 2009). The programme was originally targeted at those who have been unemployed for more than a year, aged more than 25 years and with low educational or disadvantaged backgrounds. Comparing the educational background of participants in 2008 vis-á-vis more recent years reveals that the share of persons entering the scheme with secondary or higher education attainment has increased, reflecting the persistence of long-term unemployment across the labour force. Community employment should not be expanded in its current configuration, focused on the provision of goods and services to the 
local communities, but should be limited to the most disadvantaged participants with little realistic prospects in the open labour market and for whom there is no other alternative. Its funding should be treated and budgeted as providing welfare and social support and not as an active labour market policy. The extra resources freed up should be reallocated to other schemes more effective in improving the employability of participants such as Momentum, Springboard or ICT conversion programmes (see below).

The Back to Education allowance (BTEA) accounts for a substantial proportion of the education resources available to the unemployed. BTEA is a second chance educational opportunities scheme for people on welfare payments who wish to participate in full time education, from basic foundation up to third level courses. Since 1 January 2013, the allowance is paid to new entrants at a weekly rate equivalent to the rate of the relevant social welfare payment that qualifies the applicant for participation in the scheme, with the exception of under 25 year olds who are subject to a new ceiling of EUR 160. While the scheme is generous in providing the unemployed with re-education opportunities, it resembles more a pure education allowance rather than a genuine activation programme and the linkage with labour market needs is lacking. To better align the BTEA to the labour market, job-services should take a central role in the selection of the degree that the participant is going to pursue to ensure that the qualification and skills gained are adequate to the participant profile and are relevant to the labour market, in line with the recommendation in the Department of Social Protection review (DSP, 2012). As is done in other education programmes, a link between the degrees pursuable via a BTEA and the findings of the Expert Group on Future Skills Needs Expert should be established. Access to the allowance should be aligned to the school calendar to avoid unduly long waiting periods.

The most effective ALMPs are those based on the mutual obligation principle, whereby the unemployed receive income and employment support, and in return, they are required to participate actively in job-search and/or training (Martin, 2000; Kluve, 2006). PTW has mutual obligation as one of the core underlying principles but the limited resources devoted to job-assistance and monitoring may limit its effective implementation. Some countries, such as the Netherlands, have a strict implementation of the mutual obligation approach for youth, whereby authorities are obliged to give a young person aged 18-27 who applies for social benefits an offer of work, training or a combination, and the young cannot remain inactive and must accept the offer to be entitled to social benefits. Ireland should introduce a similar stricter mutual obligation compact for youth. The first step in such a compact or youth guarantee would be to provide those in long-term unemployment and those neither in education nor in the labour force with an offer of training or work so as to keep at bay social exclusion and marginalisation.

\section{Improving the transition from school to work}

An education system that prepares youth for entering the labour market is vital from both economic and social viewpoints. Ireland ranks favourably in terms of the share of the youth population that has completed tertiary education. Nearly half of those between 25 and 34 year old have completed tertiary education, which is one of the highest rates in the OECD (OECD, 2012). In addition, around a third of the fall in youth participation in the labour market since 2009 is accounted for by a return to education (Conefrey, 2012). Nevertheless there remains a large cohort of jobless unskilled youth and Ireland is under a profound process of structural change which requires substantial labour reallocation. This requires ensuring that the training system provides skills relevant in the labour market and meets the needs of the long-term unemployed, improving the apprenticeship system and making good use of internships. The general weak situation of European Union labour markets increases the challenges. Even in low to medium skills occupations, youth must be able to compete with other youth immigrants who are often well qualified and mobile from elsewhere in the EU. 
To tackle the mounting training challenges faced by Ireland, the authorities embarked in a re-organisation of the training system (Box 2). SOLAS, the new education authority in the Department of Education and Skills, will oversee the delivery of training to the unemployed and also of further education such as vocational training. While there are potential efficiency gains in pooling the funding for unemployed training and further education, SOLAS will face major challenges in terms of supervision and coordination. A key challenge will be to ensure that the training provided is effective in addressing the needs of unemployed, in particular of long-term and other disadvantaged unemployed. For that, the training providers should be chosen according to their ability to deliver suitable instruction, irrespective of whether they are embedded in the public sector or they are private sector providers. Given scarce resources, to increase effectiveness, the provision of training should be incentivised according to the number of jobs placements achieved. Effective coordination with the Department of Social Protection (DSP) will also be vital so that DSP can assess whether the training is having the appropriate impact on the employability of the jobseekers and ensure than the training is driven by the needs of the participants, rather than provider-driven. SOLAS, in coordination with the Department of Social Protection, should establish channels to monitor the attendance at the training schemes in a timely way so that the mutual obligations underlying Pathways to Work are maintained. A target of 51000 placements has been reserved for the long-term unemployed and it is intended to intensify this in 2014.

\section{Box 2. SOLAS, the new Further Education and Training Authority}

The 33 vocational education committees, which provide further education, are being rationalised into 16 Education and Training Boards. In addition to providing for further education these Education and Training Boards will take over the responsibility for training services currently provided by FÁS. FÁS is being disbanded and a new body, SOLAS is being established. SOLAS will act as an oversight and funding body of the Further Education and Training sector. Further education encompasses a range of full and part time programmes. Fulltime schemes are: Post Leaving Certificate courses, targeted at those who have complete a Leaving certificate (secondary education) or adults reentering education; Vocational Training Opportunity Schemes, aimed at unemployed over 21 years old and leading to secondary level qualifications; Youthreach, which provides integrated education and training for early school leavers without qualification. Part-time programmes are adult literacy schemes, community education for those harder to reach and the Back to Education initiative targeted at those who have not completed the Leaving certificate qualification (secondary education).

In most countries, vocational training has been identified as a significant determinant of ensuring an efficient school-to-work transition (OECD, 2010). Employment rates of those with vocational education and general education is the second lowest in the OECD after Turkey (Figure 16). In addition, contrary to most countries, in Ireland the employment rate of individuals with general education, which in principle tends to provide skills with fewer direct links to the labour market, is higher than those with vocational education. The recession and the subsequent shift in Irish growth model have important implications on the effect that different educational qualifications have on labour market transitions (Kelly et al., 2013). Before the recession having a post-leaving certificate (PLC), the largest vocational education scheme, was associated with the best prospects for getting into employment. Lower qualifications such as leaving certificate also had a significant positive impact. After the recession, there is no significant difference in the impact that a post-leaving certificate has in comparison with lower qualifications such as a junior certificate. On the contrary, while possessing a third level non-degree did not help in the pre-recession era, after the crisis the impact is positive, likely reflecting that employment growth is taking place in higher skill areas. Holding a third level degree had a positive impact on employment prospects before the recession, and the impact has increased after the recession (Kelly et al., 2013). In order to cope with these changing requirements it is essential to establish progression plans going beyond the traditional pathways (i.e. from school to higher education). 


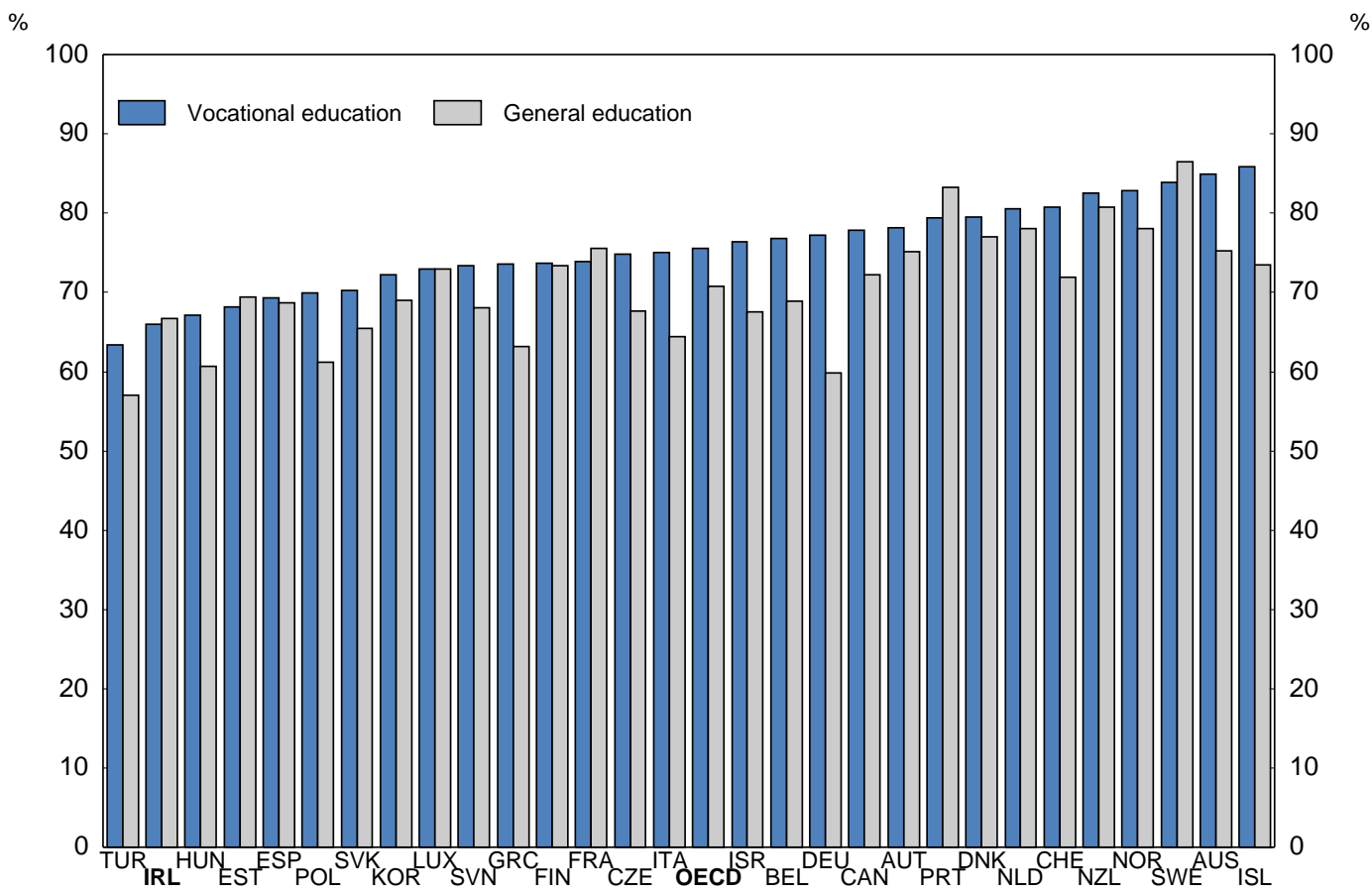

Note: Countries are ranked in ascending order of the employment rate of 25-64 year-olds with vocational education at ISCED 3-4 level.

Source: OECD Education at a Glance 2012.

Research has shown that training providing high-level skills is the most effective in increasing employability, while general training tended to provide lower returns and low-skilled training seemed to have no impact on increasing employability of participants (McGuinness et al., 2011). In order to respond to the current demands for specialized workers, the emphasis of vocational schemes should be on specialised courses providing the participant with high-level skills relevant in potential growth areas in the labour market and including a job placement component (Ashton, 2002). The recently launched Momentum programme seems to incorporate many of these elements. The programme is targeted at the long-term unemployed and will provide 6500 places in expanding employment areas of ICT, digital media, healthcare and social services, the green economy, food processing and sales and marketing. Participants in Momentum account for approximately $11 \%$ of total participants in all FAS programmes in 2013, so the scope of the programme is limited. Its effectiveness should be evaluated, and in case of positive results the programme coverage should be extended. As a general principle, education and training schemes need to be continuously evaluated so that unsuccessful schemes can be disbanded in a timely fashion and new ones set up. This is particularly important for vocational training schemes, which provide very specific skills, in some cases of limited versatility.

Apprenticeships can have large benefits for youth due to the combination of classroom and practical experience and tight linkages with employers (see Box 3). The current Irish apprenticeship system is concentrated in craft areas such as construction, the electrical sector, engineering, motor and printing. Contrary to the PLCs, whose workplace training periods have been found to be limited (Kis, 2010), apprenticeships provide abundant workplace training. Prior to the crisis the apprenticeship system provided around 8000 new registrations every year, with a high concentration on the construction sector. After the 
collapse in construction activity, registrations have stabilised at around only 1000 every year and the government has announced a review of the apprenticeship system. In order to foster and facilitate the ongoing labour reallocation, it is important that the new apprenticeship system goes beyond craft related activities and also provides skilled workers to other sectors of the economy.

The cost of apprenticeships is high in Ireland in international perspective. To improve cost-effectiveness, training on specialised equipment should take place in the company, where more up-to-date technology is available (Kis, 2010). On-going structural change in the Irish economy requires a flexible apprenticeship system where the terms of the apprenticeship depends of the needs of the specific sector, with real possibilities to create new apprenticeships rapidly enough to react to emerging needs and where resources and participants can be shifted towards those with better prospects. For that it is essential that a good level of foundation and transversal skills is ensured (Hoeckel, 2007). One key element of a successful apprenticeship and vocational system is to engage employers both in the design of the curricula and in the delivery of apprenticeship time. This is important because employers are aware of changing labour market needs. In the case of Ireland it is essential to involve SMEs, since they account for $70 \%$ of private employment. Coordinated shared training structures should be put in place to allow that smaller companies, with more limited training capabilities, can become engaged and participate in the system.

\section{Box 3. A dual system of apprenticeship and vocational training}

Countries such as Austria (OECD, 2013), Germany (Hoeckel et al, 2010) and Switzerland (Fazekas et al., 2013) have a longstanding tradition of apprenticeship systems based on a dual approach and associated with good labour market outcomes for participants. The main characteristics of the dual approach are:

- They combine learning time at a vocational school with learning time at a host company.

- Employers and social partners are engaged in the design, running and financing of the system.

- Employers get the possibility of hiring young workers "ready to work", reducing spending on recruitment and training; employees get a recognized qualification together with related and relevant work experience.

The strength of the dual apprenticeship system is that all key stakeholders, including employers, social partners (trade unions, chambers of commerce, etc.) and experts from the vocational schools, are engaged in developing the vocational training curricular frameworks. The vocational school then takes care of delivering the theoretical part of the curricula, while the private companies provide the practical part. Around $60 \%$ of the training takes part in the company. The high involvement of employers in the design of the scheme ensures a good match between the supply of and demand for skills. It also provides flexibility to respond to the requirements of the labour market and to deliver training that is adjusted to changing needs.

In Germany, special mechanisms are in place targeted at SMEs, whose training capacities may vary. This includes intercompany facilities to supplement the training hosted at some SMEs and specific structures such as the "lead enterprise with partner enterprise", whereby the lead enterprise keeps the overall training responsibility but part of the training is conducted at other partner enterprises.

Concerning higher education, to respond to the skills shortages in certain high skilled areas, the Higher Education Authority has launched Springboard and ICT skills conversion programmes. These schemes, some of which are oversubscribed, establish clear links with current and emerging labour market needs. Springboard offers part-time higher education courses for the unemployed leading to qualifications in growing and emerging sectors such as ICT, biopharma, green economy or international financial services. Recently-launched ICT Skills conversion programmes, are specifically aimed at building the supply of high-level ICT graduates. They include work-placement periods and are delivered in partnership with industry. In both cases a thorough evaluation of the outcomes of the schemes should be continuously 
undertaken. If the initial promising results found in the on-going monitoring are confirmed, the programmes should be expanded.

Internships provide a less involved structured pathway from education to work. In 2012 the DSP rolled out JobBridge, a national internship scheme aimed at individuals with a welfare entitlement in the preceding six months. The evaluation of the program (Indecon, 2013) revealed that about half of the participants have secured employment since finishing their internships. Youth participants (i.e. those between 15 and 24 years old) accounted for $29 \%$ of all participants, and the highest participation was in the 25-34 age group, which was $45 \%$ of the total. Most participants had a bachelor degree and only few had lower qualifications, such as junior or leaving certificate. Most of the participants also had significant working experience: $85 \%$ had at least one year of previous working experience. Participation declined with the duration of unemployment prior to starting the internship. One third of participants had been unemployed for less than 6 months, and $40 \%$ of participants were long-term unemployed. A third of internships took place in the Dublin area, with a lower participation in some of the counties where youth unemployment is higher.

While the scheme has served many unemployed workers with working experience to regain employment, the impact on unemployed workers without previous experience has been more limited. Given the profile of the participants, the scheme seems to have functioned more as an employer incentive scheme, which subsidised the cost of employment, rather than as a genuine internship programme aimed at facilitating the transition of inexperienced young workers to the labour market. In order to break the circle "no experience-no job-no-experience" a specific track should be established for youth (Table 2). While an ex-post evaluation of the programme has taken place (Indecon, 2013), a more thorough evaluation, based on a full control group dataset, should be undertaken to assess its effectiveness in increasing employability when taking into account participants qualifications and previous working experiences. This would also contribute to further adjusting eligibility criteria to limit potential deadweight costs associated with the scheme.

\section{Reducing labour demand barriers for youth}

Across OECD countries, the two main demand-side barriers faced by youth, and particularly by lowskilled youth, are inflexible employment protection legislation and high labour cost. Ireland retains one of the most flexible labour markets among OECD countries as measured by the OECD Employment legislation index. Despite that, the current economic uncertainty makes employers reluctant to hire on permanent contracts and they are making more use of temporary and part-time contracts (Figures 17 and 18). When faced with unemployment as the alternative, temporary and part time contracts are arguably a more favourable option. For young people entering the labour market for the first time, they can act as an initial stepping stone to permanent and full time employment.

As outsiders to the labour market, youth, in particular the low-skilled, are more likely to suffer from too high labour costs. The two main policies affecting wage and labour costs are the social security contributions paid by employers for low-pay/low-skilled workers and the minimum wage. 
To improve conditions for job creation at the lower salary band, the Irish government extended the Employer Job PRSI Incentive scheme in 2012. The scheme provides an exemption in social security contributions for employers who take on an additional member of staff who had been unemployed for 6 months or more and had the potential to benefit young unemployed workers, especially the low skilled. However, the scheme has had low take-up, likely reflecting weakness of business confidence in that period and the lack of awareness by employers. As a response, the government plans to introduce JobPlus to provide those employers who hire unemployed workers with a cash payment. This new scheme aims at obtaining a higher take-up by providing a simpler framework. Employers will receive a fixed payment over two years for hiring an individual who has been unemployed for more than 12 months. The payment will be larger if the unemployment spell has been greater than 24 months. The scheme seems well targeted to address the difficulties that the long-term unemployed are facing but there is no specific provision for youth. As in the new internship schemes, this may put them at a disadvantage to adult workers who tend to have more working experience. The scheme should be evaluated to assess whether it is successful in facilitating the access of long-term youth unemployed to employment. In case it is not, a specific track targeted at youth long-term unemployment needs to be established.

\section{Figure 17. Percentage of temporary employees ${ }^{1}$}

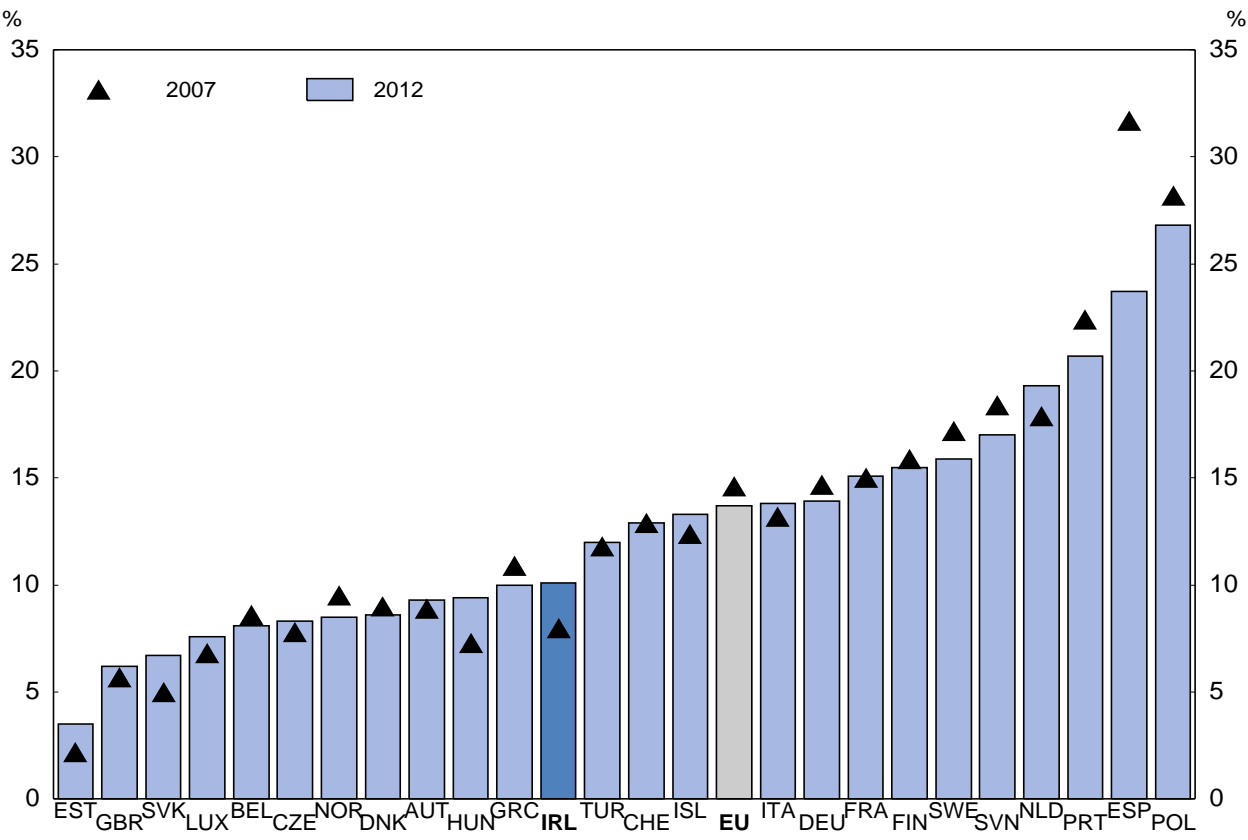

1. Persons aged 15-64.Number of temporary employees as a percentage of the total number of employees.

Source: Eurostat. 
Figure 18. Percentage of part-time employees ${ }^{1}$

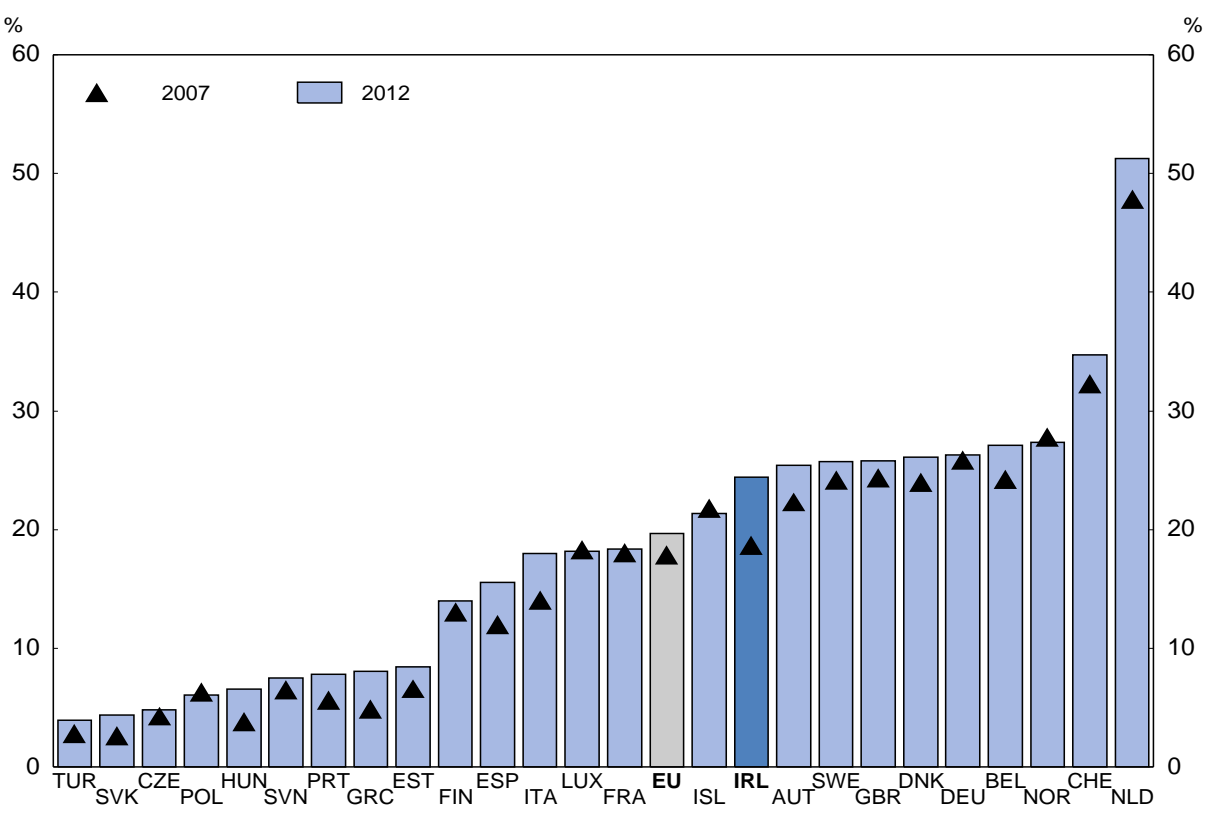

1. Persons aged 15-64. Number of part-time employees as a percentage of the total number of employees.

Source: Eurostat.

Figure 19. Minimum annual wage ${ }^{1}:$ difference between youth and adults, 2011

As a percentage of median wage

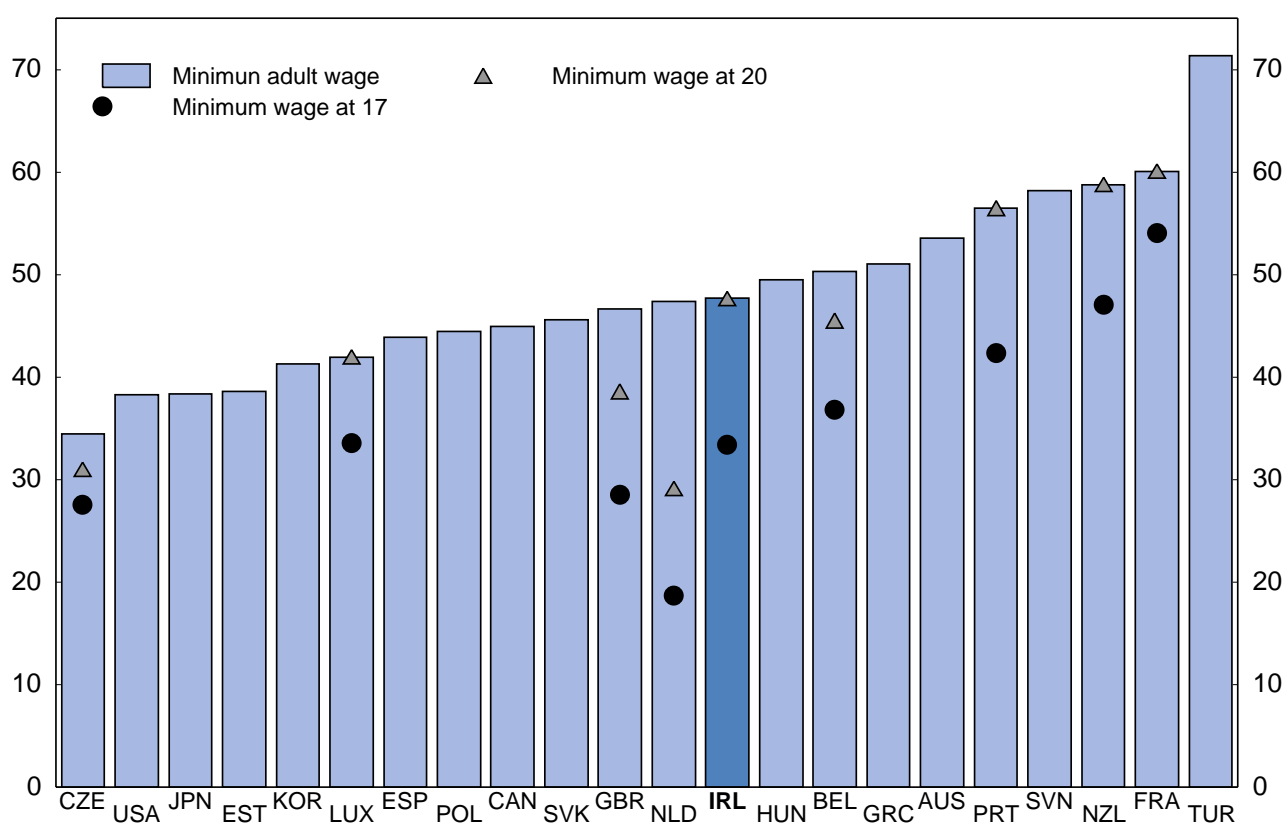

1. Data refer to the gross wage, which does not take into account potential social contribution exemptions.

Source: OECD Minimum Wages and Earnings database. 
A high minimum wage with respect to the median wage could increase the difficulties of those least productive or skilled to gain employment. In Ireland the adult minimum wage is EUR 8.65 per hour and there is a sub-minimum for youth: $70 \%$ of the adult minimum wage for those under 18 (and those who enter employment for the first time), $80 \%$ in the first year of employment since the age of 18 , and $90 \%$ in the second year. Youth sub-minima are useful in taking account productivity differentials among workers depending on their age and experience. When compared with the median wage, the statutory minimum wage in Ireland does not stand out in international perspective. The setting of youth sub-minima varies across countries. For example in the United Kingdom the sub-minimum applies to youth under 22 (Figure 19). In conjunction with other relevant parameters, the government should ensure that the level of the minimum salary, including the youth sub-minimum, does not hamper the employment of lower-skilled young workers. In addition, it is also essential that the lower skills youth cohort gets re-skilled to fulfil the productivity requirements in the service sectors that are currently creating employment. Failing to do so will put lower-skilled youth in a disadvantageous position vis-á-vis highly mobile and skilled youth workers from other European economies whose labour markets remain depressed.

\section{Supporting youth self-employment and entrepreneurship}

The self-employment rate among youth in Ireland is very low in international perspective (Figure 20). While this may partly reflect the uncertain post-crisis economic environment, the financing constraints and emigration trends, barriers to youth self-employment include a lack of exposure to entrepreneurship training and entrepreneurship as a career option.

Figure 20. Self-employment rates $^{1} 2012$

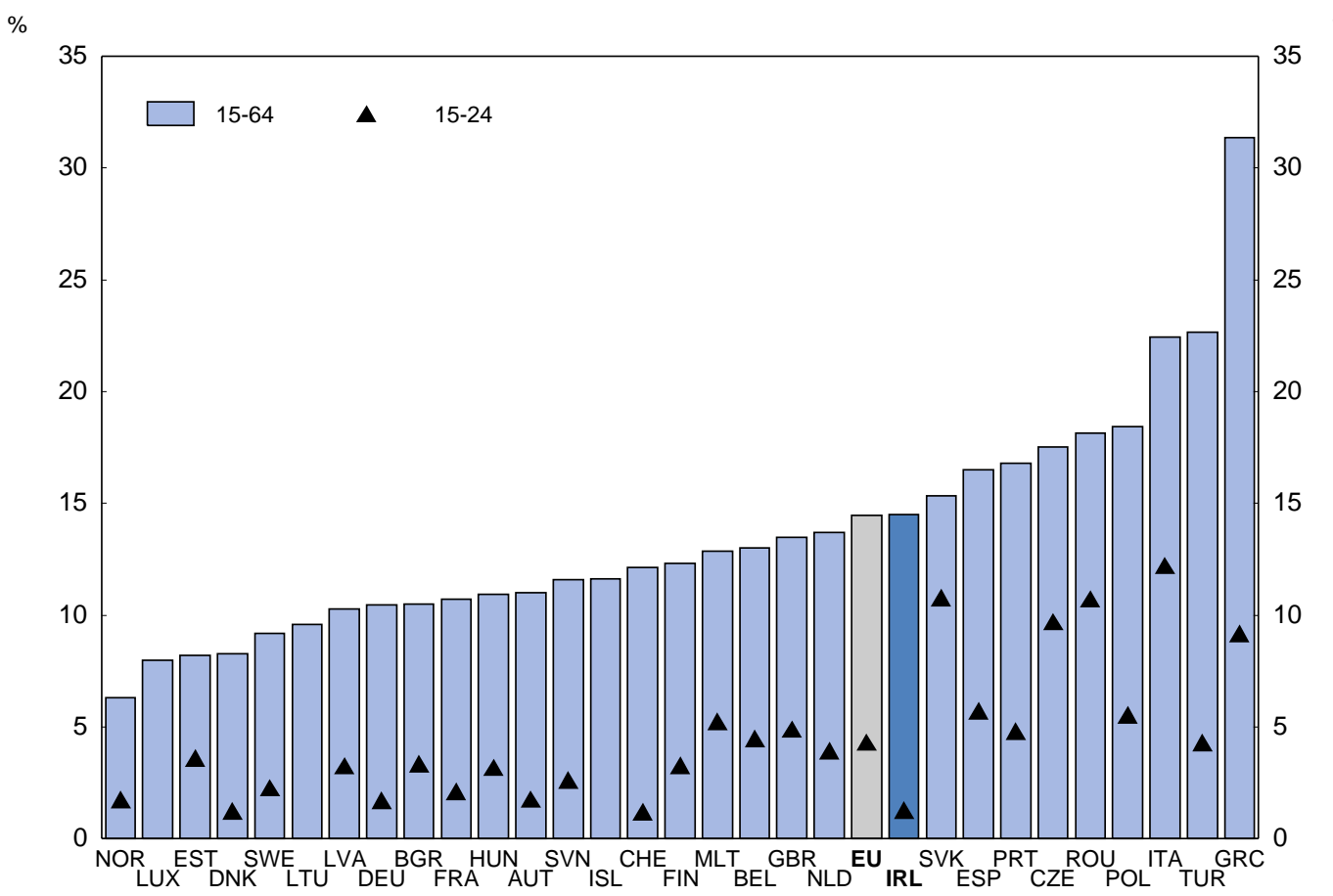

1. Self-employment as a percentage of the employment in the age group.

Source: Eurostat. 
ECO/WKP(2013)93

Table 2. Summary labour market and training schemes and recommendations

\begin{tabular}{|c|c|c|c|c|c|}
\hline Programme & Scope $^{1}$ & $\begin{array}{l}\text { Nature of } \\
\text { programme }\end{array}$ & Eligibility $^{1}$ & $\begin{array}{l}\text { Youth } \\
\text { participation }^{1}\end{array}$ & Recommendation \\
\hline $\begin{array}{l}\text { Community } \\
\text { employment }\end{array}$ & $\begin{array}{l}315 \text { EUR } \\
\text { million } \\
24000 \\
\text { participants }\end{array}$ & Work-programme & $\begin{array}{l}\text { People over } 25 \text { in } \\
\text { receipt of } \\
\text { specified social } \\
\text { welfare payments } \\
\text { for at least a year }\end{array}$ & Very marginal & $\begin{array}{l}\text { Limit to more disadvantaged cases } \\
\text { and budget as welfare and income } \\
\text { support. Reallocate freed up } \\
\text { resources to other schemes }\end{array}$ \\
\hline $\begin{array}{l}\text { Back to } \\
\text { Education } \\
\text { allowances }\end{array}$ & $\begin{array}{l}197 \text { EUR } \\
\text { million } \\
26000 \\
\text { participants }\end{array}$ & $\begin{array}{l}\text { Second chance } \\
\text { education }\end{array}$ & $\begin{array}{l}\text { Welfare payment } \\
\text { recipients for at } \\
\text { least } 3 \text { months } \\
\text { older than } 21\end{array}$ & $\begin{array}{l}\text { About } 15 \% \text { of } \\
\text { all participants } \\
\text { in } 2011\end{array}$ & $\begin{array}{l}\text { Job-services to take a central role in } \\
\text { ensuring the relevance and } \\
\text { adequacy of pursued studies }\end{array}$ \\
\hline JobBridge & $\begin{array}{l}55 \text { EUR } \\
\text { million } \\
5500 \\
\text { participants }\end{array}$ & $\begin{array}{l}\text { Internships of up } \\
\text { to nine months }\end{array}$ & $\begin{array}{l}\text { Recipients of } \\
\text { welfare claim for } \\
\text { at least three } \\
\text { months in the } \\
\text { preceding } \\
6 \text { months }\end{array}$ & $\begin{array}{l}\text { About } 33 \% \text { of } \\
\text { all participants } \\
\text { in } 2012\end{array}$ & $\begin{array}{l}\text { Establish a track for inexperienced } \\
\text { youth }\end{array}$ \\
\hline Back to work & $\begin{array}{l}127 \text { EUR } \\
\text { million } \\
6300 \\
\text { participants }\end{array}$ & $\begin{array}{l}\text { Support self- } \\
\text { entrepreneurship }\end{array}$ & $\begin{array}{l}\text { Recipients of } \\
\text { welfare claim for } \\
\text { at least } 12 \text { months }\end{array}$ & $\begin{array}{l}39 \% \\
\text { supported } \\
\text { under } \\
35 \text { years in } \\
2011\end{array}$ & $\begin{array}{l}\text { Introduce mentoring and coaching } \\
\text { for youth participants. Set-up } \\
\text { mechanisms to allow follow-up of } \\
\text { supported business }\end{array}$ \\
\hline JoBPlus & & $\begin{array}{l}\text { Encourage hiring } \\
\text { of long-term } \\
\text { unemployed }\end{array}$ & $\begin{array}{l}\text { Employers hiring } \\
\text { long-term } \\
\text { unemployed }\end{array}$ & $\begin{array}{l}\text { To be } \\
\text { assessed }\end{array}$ & $\begin{array}{l}\text { Evaluate outcome. In case youth not } \\
\text { well-covered establish a youth track }\end{array}$ \\
\hline $\begin{array}{l}\text { Training for } \\
\text { employment } \\
\text { (currently } \\
\text { provided by } \\
\text { FAS) }\end{array}$ & $\begin{array}{l}75000 \\
\text { participants }\end{array}$ & & $\begin{array}{l}\text { Unemployed by } \\
\text { referrals }\end{array}$ & & $\begin{array}{l}\text { More emphasis on high-skills and } \\
\text { driven by employers and participants } \\
\text { needs }\end{array}$ \\
\hline $\begin{array}{l}\text { Post-Leaving } \\
\text { certificate } \\
\text { (provided by } \\
\text { VECs) }\end{array}$ & $\begin{array}{l}32000 \\
\text { participants }\end{array}$ & $\begin{array}{l}\text { Vocational } \\
\text { education (post- } \\
\text { secondary) }\end{array}$ & & $\begin{array}{l}\text { Most } \\
\text { participants } \\
\text { are above } 21\end{array}$ & $\begin{array}{l}\text { More emphasis on high-skills and } \\
\text { driven by employers and participants } \\
\text { needs. Increase work-placement } \\
\text { component }\end{array}$ \\
\hline Apprenticeship & $\begin{array}{l}1400 \\
\text { participants }\end{array}$ & & & & $\begin{array}{l}\text { Expand to other areas of the } \\
\text { economy and allow for more } \\
\text { participation by SMEs }\end{array}$ \\
\hline Momentum & $\begin{array}{l}6500 \\
\text { participants }\end{array}$ & $\begin{array}{l}\text { Vocational } \\
\text { education }\end{array}$ & $\begin{array}{l}\text { Unemployed for } \\
12 \text { months or } \\
\text { more }\end{array}$ & $\begin{array}{l}\text { New program } \\
\text { starting in } \\
2013\end{array}$ & $\begin{array}{l}\text { Evaluate its outcome and expand } \\
\text { according to the result of the } \\
\text { evaluation }\end{array}$ \\
\hline Springboard & $\begin{array}{l}6000 \\
\text { participants } \\
\text { per year }\end{array}$ & $\begin{array}{l}\text { Part-time courses } \\
\text { in higher } \\
\text { education }\end{array}$ & $\begin{array}{l}\text { Unemployed } \\
\text { people }\end{array}$ & & $\begin{array}{l}\text { Evaluate its outcome and expand } \\
\text { according to the result of the } \\
\text { evaluation }\end{array}$ \\
\hline $\begin{array}{l}\text { ICT Skills } \\
\text { conversion } \\
\text { courses }\end{array}$ & $\begin{array}{l}700 \\
\text { participants }\end{array}$ & $\begin{array}{l}\text { Intensive ICT } \\
\text { training }\end{array}$ & $\begin{array}{l}\text { Graduates with } \\
\text { priority for } \\
\text { long-term } \\
\text { unemployed }\end{array}$ & & $\begin{array}{l}\text { Evaluate its outcome and expand } \\
\text { according to the result of the } \\
\text { evaluation }\end{array}$ \\
\hline
\end{tabular}

1.

DSP (2012).

To develop entrepreneurship skills among youth, entrepreneurship and the option to work for oneself could be better integrated into the Irish educational system, starting from primary education, where students may get first exposure with entrepreneurship as a career option. Evidence signals that programmes aimed at instilling entrepreneurial attitudes and competencies in secondary education are effective in increasing the entrepreneurial intentions of participants, have a significant effect on the self-perceived 
feasibility to start a company and increase the perceived desirability of the self-employment option (Lepoutre et al, 2010). Providing information, advice, coaching and mentoring, facilitating access to financing and offering support infrastructure for business start-up are also important elements (OECD, 2012b). While Ireland has in place specific programmes to support entrepreneurship by specific groups, e.g. Enterprise Ireland provides the Competitive Feasibility Fund for Female Entrepreneurs targeted at female-led new start-ups, there is no specific provision for youth entrepreneurship so far.

Back to Work Enterprise Allowance and Short-term Enterprise Allowance are programmes supporting self-employment among those on social welfare payments. In neither of these schemes there are specific support provided to youth and there is no follow-up concerning outcomes and survival rates of the business supported by the schemes. In order to allow for a more efficient and effective delivery of the schemes, the allowances should be granted in conjunction with a coaching and mentoring package especially when these schemes are granted to young unemployed. A centralized gathering of information related to the schemes should be developed to allow for a proper evaluation and follow-up of the supported business.

\section{Better integration of disadvantaged youth}

Standard policies are unlikely to work for disadvantaged youth i.e. those young workers who are disadvantaged by their personal circumstances from entering or re-entering the labour market, including youth of disfavoured social background or those with health problems or disability. Alternative schemes, such as the ones being provided by Youthreach, where participants received more inclusive and specialized attention, including adult mentoring, seem to offer good outcomes. Skill-upgrading should be tailored to the profile of the disadvantaged youth (OECD, 2010), and for that, the existing profiling models should be adapted to identify targeted pathways to work also for these people. Early action, and in particular enrolment in early childhood and primary education, has been identified as an effective way to mitigate social inequalities and avoid the perpetuation of social exclusion and poverty (Carneiro and Heckman, 2003; Caille and Rosenwald, 2006). Ireland's enrolment rate has increased but remains well below the OECD average (Figure 21). Efforts should be made to increase early childhood education as a preventive way to better integrate youth with more disfavoured social and economic backgrounds. This is also pertinent given the structural problems of workless households that Ireland suffers, with a high share of children living with lone-parents.

Ireland has the highest proportion of population in jobless households in the EU, and it was the second highest prior to the recession (Watson et al., 2012). The risk of long-term poverty is much higher for jobless individuals on benefits than for employed people. It is important that the tax and welfare systems operate to minimise disincentives to work especially for low-wage workers. This requires a careful and granular review of the interactions between tax and benefits for certain segments of the population to make work pay more vis-à-vis benefit receipt.

Employment rates of people with health problems or disability were already among the lowest in the OECD before the crisis, which signals some structural difficulties in accessing the labour market for these groups. Despite some recent changes, disability policy in Ireland remains mostly passive with little conditionality for the disabled group. Over the period 2000-10 the number of recipients of disability and illness allowances rose by 48\% from 184500 to 275000 (DSP, 2012). The increase occurred in a context of general improvement in health and living conditions and strong demand for labour up to 2008, and partly reflects the easing of the conditions to access disability benefits as opposed to tighter conditions for unemployment benefits. At the end of December 2010 the Department of Social Protection introduced a Partial Capacity Benefit scheme with the intention of changing the current structure of the welfare system, which categorises people as 'fit to work' or 'unfit to work' and does not take into account those who have some capacity to work. This change is in the right direction; however, participation in the scheme remains 
on a voluntary basis. Ireland is among the minority of OECD countries where young people can access disability benefits at the age of 16 . DSP can refer young people to a mainstream training or to a specialist training provision. Nonetheless, no conditionality is imposed on benefit recipients. Disability benefit for young people should be more linked to participation in a targeted strategy towards reintegration in education or in the labour market.

Figure 21. Enrolment rates in early childhood and primary education at age 4

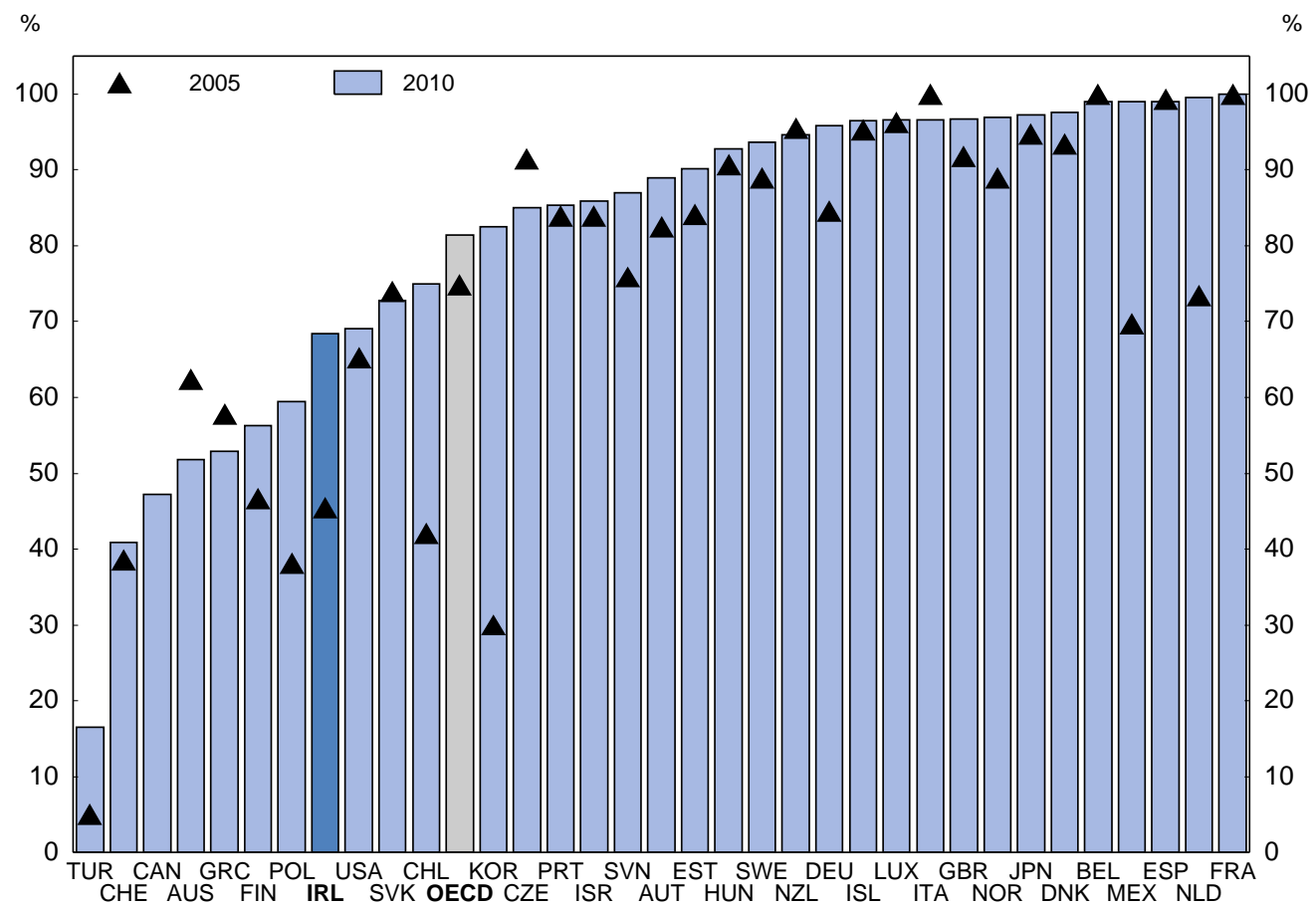

Note: The OECD area is the simple average.

Source: OECD Education database.

Mental health problems are increasingly becoming a major cause of labour market exclusion in many OECD countries (OECD, 2012c), and international evidence suggest that long-term unemployment can have significant negative effects on mental health (Paul and Moser, 2009). It is key that youth suffering from long-term unemployment receive adequate psychological support. The National Psychological Services (NPS) seem to have some good attributes including providing comprehensive psychological support in schools to intervene early and preventing mental health problems arising in the first place. However, as in other OECD countries, the ratio of individuals supported to psychologist is very high. Going forward, the role of the NPS and its capacity need to be stepped up to assist the employment services, particularly in supporting young people in long-term unemployment at risk of social exclusion and marginalisation.

Irish social enterprises have played a valuable role in fighting social exclusion through the number of disadvantaged or marginalised people they employ, but the sector remains comparatively under utilised in comparison with other European countries. Encompassing both nonprofit institutions and for-profits whose driving purpose is social, the social enterprise sector has the potential to provide significantly greater public returns by improving local communities and give youth more detached from the labour market additional working opportunities. In order to achieve such potential, the social enterprise sector, including 
non-profits organizations, should be able to access the same kinds of government support as conventional enterprises including access to finance, knowledge sharing and business support services.

\section{Box 4. Recommendations for getting Irish youth on the job track}

\section{Activating youth}

To minimize the detrimental and enduring impact of long-term unemployment, establish a youth compact whereby those in unemployment will receive a compulsory offer of training, work or a combination.

To provide job-search assistance and activate the current cohort of long-term young unemployed, increase the number of caseworkers in the public employment service through internal redeployment.

Establish specific youth tracks in those schemes where youth is having difficulties to access (Table 1.2).

\section{Fostering labour reallocation}

To respond to the demand for specialised skills, concentrate training efforts in those schemes providing high level skills such as Momentum, Springboard or ICT conversion courses. Progression pathways between different education levels should be stepped-up.

To provide skilled workers to emerging sectors, expand the apprenticeship beyond craft-related areas involving the SME sector, better align curricula of vocational training to unemployed profiles and to employers demands and increase its workplace component.

\section{Delivering cost-effective ALMPs}

Establish a systematic and rigorous evaluation of all policies and schemes including sunset clauses to review at regular intervals the need for extensions. Based on the evaluation, reallocate resources to those schemes which are found to be effective in increasing employability (Table 1.2).

To adapt Pathways to Work to the changing structure of the Irish economy, establish a regular review and evaluation of the profiling model. Enlarge the model to encompass those more detached from the labour market.

\section{Supporting youth entrepreneurship}

Establish a strategy to provide youth with relevant training and support. Introduce mentoring and coaching in the existing programme supporting self-entrepreneurship among unemployed.

\section{Better integrating disadvantaged youth}

To reduce poverty risk and social exclusion, put a stronger emphasis on encouraging and facilitating the return to education or employment of those more unattached from the labour market by increasing mutual obligation approaches.

Step-up the role and the capacity of psychological services to assist employment services in supporting young people and increase early childhood education as a preventive way to better integrate disfavored youth.

To realise its potential in the social inclusion of disadvantaged people, the social enterprise sector, including non-profits organizations, should be able to access the same kinds of government support as conventional enterprises. 


\section{Bibliography}

Arulampalam, Wiji, Paul Gregg, and Mary Gregory. (2001). "Unemployment Scarring," Economic Journal, Vol. 111, F577-F584.

Ashton, D (2002), "Supporting workplace learning for high performance working", International Labour Office, Geneva.

Bergin, A., and Kearney, I. (2007), "Human capital accumulation in an open labour market: Ireland in the 1990s", Economic Modelling, Vol. 24, pp. 839-858.

Bell, David N.F. \& Blanchflower, David G., 2011. "Young People and the Great Recession", IZA Discussion Papers 5674, Institute for the Study of Labour (IZA).

Blundell, R. (2006) "Earned income tax credit policies: Impact and optimality. The Adam Smith Lecture, 2005", Labour Economics Vol. 13, pp. 423-443.

Byrne, D., Frances McGinnity, Emer Smyth \& Merike Darmody (2010): Immigration and school composition in Ireland, Irish Educational Studies, Vol. 29:3, pp. 271-288.

Caille, J.-P. and F. Rosenwald (2006), "Les inégalités de réussite à l'école élémentaire: construction et évolution”, France Portrait Social, INSEE, Paris.

Card, D., J. Kluve, and A. Weber (2010): “Active Labour Market Policy Evaluations: A Meta-Analysis,", Economic Journal, 120(548), F452-F477.

Carneiro, P. and J. Heckman (2003), "Human Capital Policy”, IZA Discussion Paper, No. 821, Bonn.

Conefrey, T. (2011), "Unemployment and Labour Force Participation during the Recession”, Central Bank of Ireland Economic Letters Series Vol. 2011, No. 4.

Conefrey, T. (2013), "Migration in Ireland: Recent Trends in Historical Context". Box in Central Bank of Ireland's Quarterly Bulletin 01/January 2013.

Crépon, Bruno, Esther Duflo, Marc Gurgand, Roland Rathelot, and Philippe Zamora (2013), "Do Labour Market Policies Have Displacement Effects? Evidence from a Clustered Randomized Experiment", Quarterly Journal of Economics, 128(2).

Crowley, L., K. Jones, N. Cominetti and J. Gulliford (2013), "International Lessons: Youth unemployment in the global context", The Work Foundation, Lancaster University, April 2012.

Central Statistics Office (CSO) (2013), Quarterly National Household Survey, Quarter 12013.

Department of Social Protection (DSP) (2012), “A Review of Department of Social Protection Employment Support Schemes".

Education, Audiovisual and Culture Executive Agency (Eurydice, 2012), The European Higher Education Area in 2012: Bologna Process Implementation Report, Brussels. 
Eissa, N. and H.W. Hoynes (2005), "Behavioral responses to taxes: Lessons from the EITC and labor supply", NBER Working Paper 11729.

Fitz Gerald, J.,et al., (2008), "Medium-Term Review: 2008-2015”, Dublin: The Economic and Social Research Institute.

Gautier, Pieter \& Muller, Paul \& van der Klaauw, Bas \& Rosholm, Michael \& Svarer, Michael, (2012), "Estimating Equilibrium Effects of Job Search Assistance", IZA Discussion Papers 6748, Institute for the Study of Labor (IZA).

Government of Ireland (2012), Pathways to Work: Government Policy Statement on Labour Market Activation, Dublin.

Gilmartin, M. (2012), “The changing landscape of Irish migration, 2000-2012”, NIRSA Working Paper Series, No. 69 - Oct 2012.

Grubb, D. and J. Martin (2001), 'What works and for whom: a review of OECD countries' experiences with active labour market policies', OECD Office of Labour Market Policy Evaluation Working Paper 2001:14.

Hoeckel, K. (2007), "Key Evidence on Vocational Education and Training Policy from Previous OECD Work", OECD Publishing, Paris.

Hoeckel, K. and R. Schwartz (2010), "Learning for Jobs OECD Reviews of Vocational Education and Training - GermanyKey", OECD Publishing, Paris.

Indecon (2013), "Evaluation of JobBridge”, Indecon International Economic Consultants.

Johnston, D. (2006), "Lessons to be learnt? The role of evaluations of active labour market programmes in evidence-based policy making", Public Administration and Development, Vol. 26, Issue 4.

Kelly, Elish \& McGuinness, Seamus \& O'Connell, Philip J., (2011), "What Can Active Labour Market Policies Do?", Renewal Series, Paper 1, Economic and Social Research Institute (ESRI).

Kelly, Elish \& McGuinness, Seamus \& O'Connell, Philip J., (2011), "Transitions to long-term unemployment risk among young people: evidence from Ireland", Journal of Youth Studies, Vol. 15:6, pp. 780-801.

Kelly, Elish \& McGuinness, Seamus \& O'Connell, Philip J. \& Haugh, D. and González Pandiella, A. (2013), "Transitions in and out of Unemployment among Young People in the Irish Recession", OECD Economics Department Working Paper, No. 1084.

Kluve, J. (2006), “The Effectiveness of European Active Labour Market Policy”, IZA Discussion Paper No. 2018.

Krueger, A. and A. Mueller (2011), "Job Search, Emotional Well-Being, and Job Finding in a Period of MassUnemployment: Evidence from High-Frequency Longitudinal Data", Brookings Papers on Economic Activity, Vol. 42, No. 1, pp. 1-57.

Lepoutre, Jan, et al., 2010, 'A new approach to testing the effects of entrepreneurship education among secondary school pupils', Vlerick Leuven Gent Working Paper Series 2010/01.Fazekas, M. and Simon Field (2013), "A Skills beyond School Review of Switzerland”, OECD Publishing, Paris. 
Lallemand, T. and F. Ryckx (2009), “Are young and older workers harmful for firm productivity?", Institute for the Study of Labour (IZA) Discussion Paper No. 3938.

Martin, J. (2000), "What Works Among Active Labour Market Policies: Evidence From OECD Countries' Experiences", OECD Economic Studies, No. 30.

Machin, Stephen, and Alan Manning. (1999), "The Causes and Consequences of Longterm Unemployment in Europe". In Handbook of Labor Economics Vol. 3, edited by Orley Ashenfelter and David Card, pp. 3085-3139, Amsterdam: Elsevier.

McGuinness, S., P.J. O’Connell, E. Kelly and J.R. Walsh (2011), “Activation in Ireland: An Evaluation of the National Employment Action Plan", ESRI Research Series No. 20. Dublin: Economic and Social Research Institute.

McGuinness, S, O'Connell, Philip J, Kelly, Elish (2011a), “One Dummy Won't Get it: The Impact of Training Programme Type and Duration on the Employment Chances of the Unemployed in Ireland", ESRI Working Paper 410.

McGinnity, F., Emma Quinn, Philip O'Connell and Nora Donnelly (2011), “Annual Monitoring Report on Integration. How are immigrants integrating into Irish society?", Economic and Social Research Institute.

O’Connell, P.J., S. McGuinness, S. E. Kelly and J. Walsh, (2009), "National Profiling of the Unemployed in Ireland", ESRI Research Series No. 10, Dublin: Economic and Social Research Institute.

Prskawetz, A., B. Mahlberg, V. Skirbekk, I. Freund, M. Winkler-Dworak, T. Lindh, B. Malmberg, O. S. Nordström and F. Andersson (2006), "The Impact of Population Ageing on Innovation and Productivity Growth in Europe", Research report No. 28 for the European Commission, Employment, Social Affairs and Equal Opportunities DG, Vienna Institute of Demography.

Puig-Barrachina, Vanessa, Davide Malmusi, José Miguel Martínez, Joan Benach, (2011), "Monitoring Social Determinants of Health Inequalities: The Impact of Unemployment among Vulnerable Groups", International Journal of Health Services. Issue: Vol. 41, No. 3/2011.

OECD (2008b), Employment Outlook, OECD Publishing, Paris.

OECD (2010), Off to a good start? Jobs for youth, OECD Publishing, Paris.

OECD (2011), OECD Economic Surveys Ireland, OECD Publishing, Paris.

OECD (2012), Education at a Glance, OECD Publishing, Paris.

OECD (2012b), "Entrepreneurial Activities in Europe" - Policy Brief on Youth Entrepreneurship.

OECD (2012c), Sick on the Job? Myths and Realities about Mental Health and Work, OECD Publishing, Paris.

OECD (2013), OECD Economic Surveys Austria, OECD Publishing, Paris.

O'Connell, P.J., S. McGuinness, E. Kelly and J.R. Walsh (2009), National Profiling of the Unemployed in Ireland, ESRI Research Series No. 10. Dublin: Economic and Social Research Institute. 


\section{ECO/WKP(2013)93}

Paul, K. I., and Moser, K. (2009),'Unemployment impairs mental health: Meta-analyses”, Journal of Vocational Behavior 74(3), pp. 264-282.

The European Monitoring Centre for Drugs and Drug Addiction (EMCDDA), 2011 ESPAD survey.

Walsh, B. \& Walsh, D. (2011), "Suicide in Ireland: The Influence of Alcohol and Unemployment", The Economic and Social Review, Vol. 42, , pp. 27-47.

Watson, D, Maitre, B and Whelan, C.T. (2012), "Work and Poverty in Ireland: An Analysis of the CSO Survey on Income and Living Conditions 2004-2010", Social Inclusion Report No. 3. Dublin: Department of Social Protection. 


\section{WORKING PAPERS}

The full series of Economics Department Working Papers can be consulted at www.oecd.org/eco/workingpapers/

1100. New econometric estimates of long-term growth effects of different areas of public spending (November 2013) by Omar Barbiero and Boris Cournède

1099. Cross-country spillovers from fiscal consolidations

(November 2013) by Antoine Goujard

1098. Informal employment in Russia: Definitions, incidence,determinants and labour market segmentation (November 2013) by Hartmut Lehmann and Anzelika Zaiceva

1097. Capacity needs in the automobile industry in the short- to medium run (November 2013) by Caroline Klein and Isabell Koske

1096. Environmental policies and productivity growth - a critical review of empirical findings

(November 2013) by Tomasz Koźluk and Vera Zipperer

1095. Green growth challenges and the need for an energy reform in Mexico

(November 2013) by Carla Valdivia de Richter

1094. From bricks to brains: increasing the contribution of knowledge-based capital to growth in Ireland (November 2013) by David Haugh

1093. China's March to Prosperity: Reforms to Avoid the Middle-Income Trap

(November 2013) by Vincent Koen, Richard Herd and Sam Hill

1092. Multi Factor Productivity with natural capital

(November 2013) by Nicola Brandt, Paul Schreyer and Vera Zipperer

1091. Growth-promoting policies and macroeconomic stability

(October 2013) by Douglas Sutherland and Peter Hoeller

1090. Policies for inclusive urbanisation in China

(October 2013) by Vincent Koen, Richard Herd, Xiao Wang and Thomas Chalaux

1089. Fiscal devaluation - can it help to boost competitiveness?

(October 2013) by Isabell Koske

1088. How to achieve growth- and equity-friendly fiscal consolidation? A proposed methodology for instrument choice with an illustrative application to OECD countries

(October 2013) by Boris Cournède, Antoine Goujard and Álvaro Pina

1087. Improving school-to-work transition in New Zealand

(September 2013) by Alexandra Bibbee

1086. The agri-food situation and policies in Switzerland

(September 2013) by Peter Jarrett and Charlotte Moeser 
1085. Japan's challenging debt dynamics

(August 2013) by Yvan Guillemette and Jan Strasky

1084. Transitions in and out of unemployment among young people in the Irish recession (August 2013) by Elish Kelly, Seamus McGuinness, Philip O'Connell, David Haugh and Alberto González Pandiella

1083. Is there convergence of Russia's regions? Exploring the empirical evidence: 1995-2010 (August 2013) by Hartmut Lehmann and Maria Giulia Silvagni

1082. The benefits and costs of highly expansionary monetary policy

(August 2013) by Łukasz Rawdanowicz, Romain Bouis and Shingo Watanabe

1081. The effectiveness of monetary policy since the onset of the financial crisis

(August 2013) by Romain Bouis, Łukasz Rawdanowicz, Jean-Paul Renne, Shingo Watanabe and Ane Kathrine Christensen

1080. Responding to key well-being challenges in Austria

(August 2013) by Rauf Gönenç, Oliver Röhn, Christian Beer and Andreas Wörgötter

1079. Austria's well-being goes beyond GDP

(August 2013) by Oliver Röhn, Rauf Gönenç, Christian Beer and Romina Boarini

1078. Improving fiscal federal relations for a stronger Mexico

(August 2013) by Aida Caldera Sánchez

1077. Deleveraging: challenges, progress and policies

(August 2013) by Romain Bouis, Ane Kathrine Christensen and Boris Cournède

1076. Policies to support sustainable long-term growth in New Zealand

(July 2013) by Calista Cheung

1075. Do structural policies affect macroeconomic stability?

(July 2013) by Volker Ziemann

1074. A simple fiscal stress testing model - case studies of Austrian, Czech and German economies (July 2013) by Ondra Kamenik, Zdenek Tuma, David Vavra and Zuzana Smidova

1073. Road connectivity and the border effect: evidence from Europe

(July 2013) by Henrik Braconier and Mauro Pisu

1072. Fiscal consolidation across government levels. Part 3: Intergovernmental grants, pro- or counter-cyclical?

(July 2013) by Hansjörg Blöchliger and Balázs Égert

1071. Fiscal consolidation across government levels. Part 2: Fiscal rules for sub-central governments, update of the institutional indicator

(July 2013) by Kaja Fredriksen

1070. Fiscal consolidation across government levels. Part 1: How much, what policies?

(July 2013) by Hansjörg Blöchliger 